Review

\title{
Ciguatera Mini Review: 21st Century Environmental Challenges and the Interdisciplinary Research Efforts Rising to Meet Them
}

\author{
Christopher R. Loeffler 1,2,*(D), Luciana Tartaglione ${ }^{2,3}$, Miriam Friedemann ${ }^{4}$, Astrid Spielmeyer ${ }^{1}$, \\ Oliver Kappenstein ${ }^{1}$ (D) and Dorina Bodi ${ }^{1}$
}

Citation: Loeffler, C.R.; Tartaglione, L.; Friedemann, M.; Spielmeyer, A.; Kappenstein, O.; Bodi, D. Ciguatera Mini Review: 21st Century Environmental Challenges and the Interdisciplinary Research Efforts Rising to Meet Them. Int. J. Environ. Res. Public Health 2021, 18, 3027. https://doi.org/10.3390/ ijerph18063027

Academic Editors: Josep Lloret and Bruce Maycock

Received: 15 February 2021

Accepted: 12 March 2021

Published: 15 March 2021

Publisher's Note: MDPI stays neutral with regard to jurisdictional claims in published maps and institutional affiliations.

Copyright: (C) 2021 by the authors Licensee MDPI, Basel, Switzerland. This article is an open access article distributed under the terms and conditions of the Creative Commons Attribution (CC BY) license (https:// creativecommons.org/licenses/by/ $4.0 /)$
1 National Reference Laboratory of Marine Biotoxins, Department Safety in the Food Chain, German Federal Institute for Risk Assessment, Max-Dohrn-Str. 8-10, 10589 Berlin, Germany; Astrid.Spielmeyer@bfr.bund.de (A.S.); Oliver.Kappenstein@bfr.bund.de (O.K.); Dorina.Bodi@bfr.bund.de (D.B.)

2 Department of Pharmacy, School of Medicine and Surgery, University of Napoli Federico II, Via D. Montesano 49, 80131 Napoli, Italy; luciana.tartaglione@unina.it

3 CoNISMa-National Inter-University Consortium for Marine Sciences, Piazzale Flaminio 9, 00196 Rome, Italy

4 Department Exposure, German Federal Institute for Risk Assessment, Max-Dohrn-Str. 8-10, 10589 Berlin, Germany; Miriam.Friedemann@bfr.bund.de

* Correspondence: Christopher.Loeffler@bfr.bund.de

\begin{abstract}
Globally, the livelihoods of over a billion people are affected by changes to marine ecosystems, both structurally and systematically. Resources and ecosystem services, provided by the marine environment, contribute nutrition, income, and health benefits for communities. One threat to these securities is ciguatera poisoning; worldwide, the most commonly reported non-bacterial seafood-related illness. Ciguatera is caused by the consumption of (primarily) finfish contaminated with ciguatoxins, potent neurotoxins produced by benthic single-cell microalgae. When consumed, ciguatoxins are biotransformed and can bioaccumulate throughout the food-web via complex pathways. Ciguatera-derived food insecurity is particularly extreme for small island-nations, where fear of intoxication can lead to fishing restrictions by region, species, or size. Exacerbating these complexities are anthropogenic or natural changes occurring in global marine habitats, e.g., climate change, greenhouse-gas induced physical oceanic changes, overfishing, invasive species, and even the international seafood trade. Here we provide an overview of the challenges and opportunities of the 21st century regarding the many facets of ciguatera, including the complex nature of this illness, the biological/environmental factors affecting the causative organisms, their toxins, vectors, detection methods, human-health oriented responses, and ultimately an outlook towards the future. Ciguatera research efforts face many social and environmental challenges this century. However, several future-oriented goals are within reach, including digital solutions for seafood supply chains, identifying novel compounds and methods with the potential for advanced diagnostics, treatments, and prediction capabilities. The advances described herein provide confidence that the tools are now available to answer many of the remaining questions surrounding ciguatera and therefore protection measures can become more accurate and routine.
\end{abstract}

Keywords: ciguatera poisoning; Gambierdiscus; fisheries management; ciguatoxin; harmful algae; marine toxins; human health

\section{Introduction}

The identified risks, impacts, and challenges faced in the 21st century are numerous, encompassing economic, geopolitical, societal, technological, and environmental pressures [1]. Worldwide, oceans are enduring anthropogenically induced hazards and impacts including changes to physical conditions (e.g., nutrient loads [2], ocean $\mathrm{pH}$, and warming waters [3]), ecosystem wide disturbances, and disruptions to ecosystem services and 
the fisheries industry, as highlighted by the Intergovernmental Panel on Climate Change (Figure 1) [4]. Any reduction in the supply of seafood products would negatively impact the livelihoods and primary source of animal protein for over one billion people around the world [5]. Signs of biological or ecological disturbances that threaten seafood security can include: (a) loss of marine biodiversity (including the loss of rare but functionally important organisms), (b) lower biomass (community or species), (c) loss of habitat, (d) the spreading of invasive species, or (e) increases in harmful algae and hypoxic dead zones. Small island developing states and their artisanal fisheries are particularly vulnerable to these seafood insecurities and are dependent upon a secure local seafood supply [6,7]. Otherwise, they risk becoming increasingly dependent on imported foods and foreign assistance programs [6,8,9]. Therefore, it is a major stated goal of the Food and Agriculture Organization of the United Nations to increase the contribution of small-scale fisheries to alleviate poverty and food insecurity [6,8].

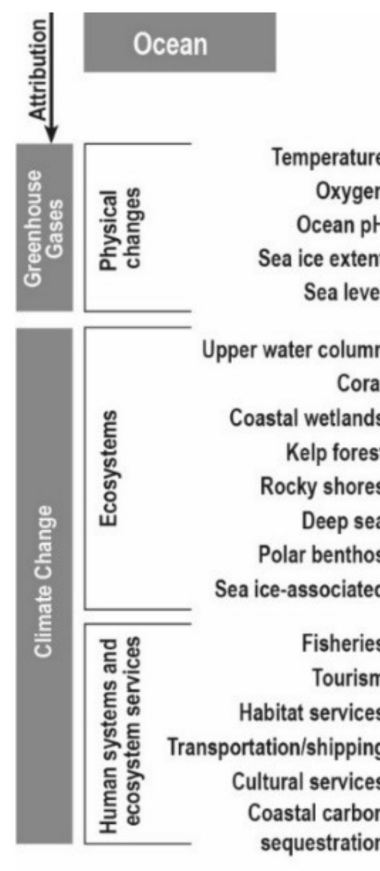

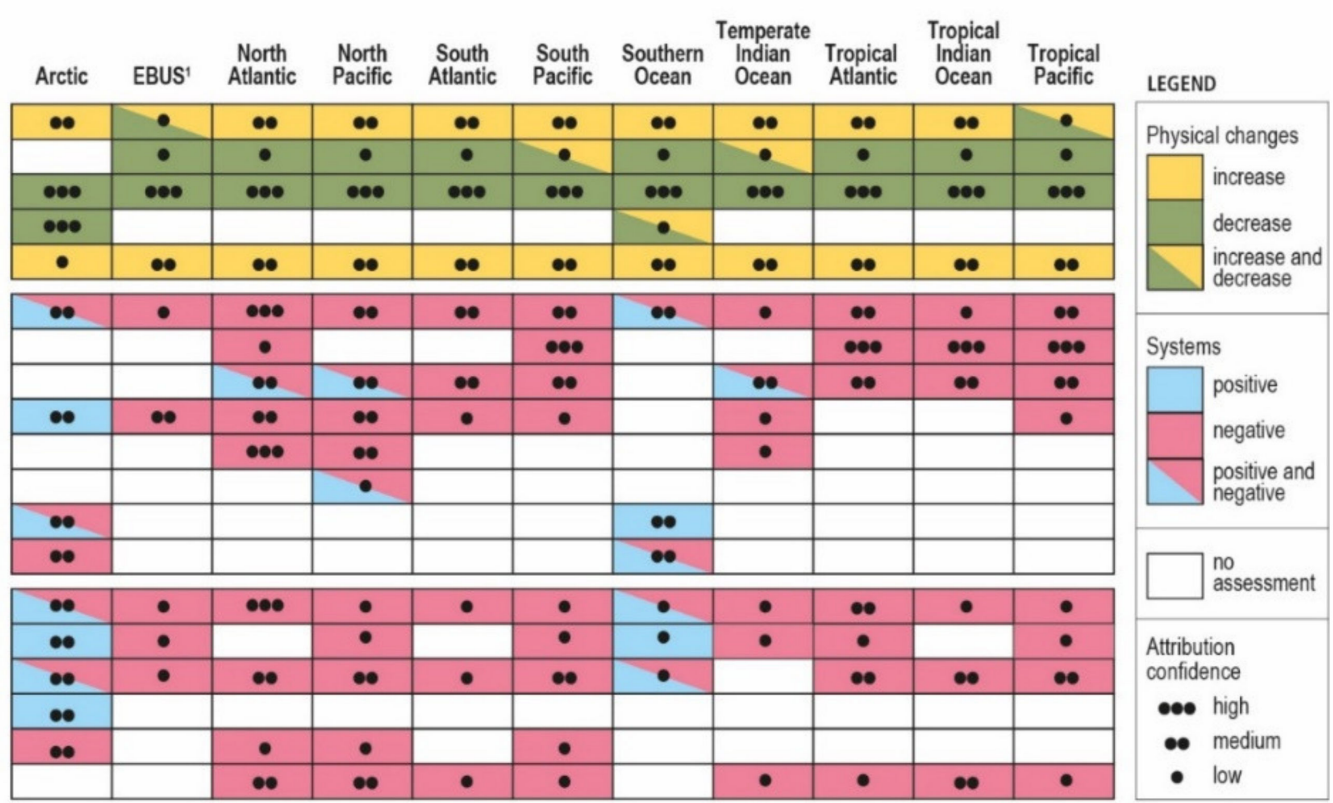

${ }^{1}$ Eastern Boundary Upwelling Systems (Benguela Current, Canary Current, California Current, and Humboldt Current); $\{$ Box 5.3\}

Figure 1. Synthesis of observed regional hazards and impacts in the ocean, assessed in the 'Special report on the ocean and cryosphere in a changing climate' (Figure 5.24 in the report). Detailed information about the legend and classification data are provided therein [4]. Many of these changes directly or indirectly influence the issue of ciguatera, as outlined in this manuscript.

A major impediment to this goal is a serious health threatening issue called ciguatera, responsible for significant harvest restrictions to avoid primary health risk-associated products [10-14]. Ciguatera poisoning (CP), often referred to simply as 'ciguatera', is the most commonly reported seafood toxin-related illness, endemic to many tropical and subtropical regions around the world and caused by the ingestion of seafood contaminated with potent neurotoxins, mainly ciguatoxins (CTXs) $[11,15,16]$. In general, shallow, warm water, marine habitats $(<200 \mathrm{~m}$, down to $<1 \%$ of ambient surface irradiance, $>16^{\circ} \mathrm{C}$, and $>15$ salinity) can support a population of benthic dinoflagellates in the genera Gambierdiscus and Fukuyoa $[17,18]$. Species in these genera can produce CTXs $[19,20]$, and/or other bioactive ladder-shaped polyether compounds; such as gambierol [21], gambieroxide [22], gambieric acids [23], gambierone [24], 44-methyl gambierone [25-27], or maitotoxins (MTXs) [26,28-32], as summarized by the FAO and WHO [16]. Primary consumers (herbivores, planktivores, detritivores, omnivores, and possibly zooplankton) directly or indirectly consume Gambierdiscus and/or Fukuyoa, inadvertently acquiring their toxic compounds or toxins. CTXs (and potentially MTXs [33]), in particular, can 
bioaccumulate and become biotransformed in the consumer and move throughout the food-web via complex poorly understood predator/prey pathways, ultimately reaching humans when these toxin containing animals are consumed [25,33-39].

CTXs (CTX1B LD $50=0.25 \mu \mathrm{g} / \mathrm{kg}$, mice, i.p. [40]), the presumed causative agent of CP outbreaks, and MTXs (MTX-1 $\mathrm{LD}_{50}=50 \mathrm{ng} / \mathrm{kg}$, mice, i.p. [28]), are among the most toxic natural substances known and no specific antidotes for the illnesses caused by them exist [41,42]. CP occurrences by region can be found in Figure 2A [43] along with satellite-derived monthly average sea surface temperature $\geq 15^{\circ} \mathrm{C}$ for the global peak summer (Figure 2B) and winter (Figure 2C) seasons of 2020. This set of images shows CP endemic areas and the territories with emerging incidences since the beginning of this century (Figure 2A), and where the most recent extent of thermal tolerance (Figure 2B,C) is likely to already be suitable for seasonal habitability for the species involved in $\mathrm{CP}$. Where habitats become suitable for the presence of Gambierdiscus spp. and Fukuyoa spp., (here after Gambierdiscus and Fukuyoa unless specified) they likely signal the potential for future $\mathrm{CP}$ events where harvest areas or species considered 'safe' may transition to 'emerging area/species of concern' [44]. Ciguatera incidences are expected to increase, due to an accelerated expansion of the toxin-producing microalgae, which are based on forecasts and data-driven models of sea-level rise and warming waters [45,46] resulting from climate change and anthropogenic impacts [47-54].

The ciguatera-issue, as a whole, poses a problem for a multitude of specialists, from phycologists working on unraveling the many mysteries of microalgae to physicians and psychologists determined to help patients better understand and recover from the long-term neurological and psychological damage induced by $\mathrm{CP}[16,55]$. Thus, ciguatera provides a strong case study demonstrating the importance of inter- and intra-agency multidisciplinary cooperative approaches for the transfer of shared working materials, training, and knowledge dissemination in order to advance the understanding of this complex phenomenon. From an environmental perspective on $\mathrm{CP}$, there are many uncertainties to estimating the impact of biotic or abiotic, physical, spatial, and temporal changes to an ecosystem and food web regarding their role in dampening or exacerbating the $\mathrm{CP}$ issue. Both human and environmental factors are interdependent and further contribute to the severity and uncertainty around the impacts of ciguatera globally. 

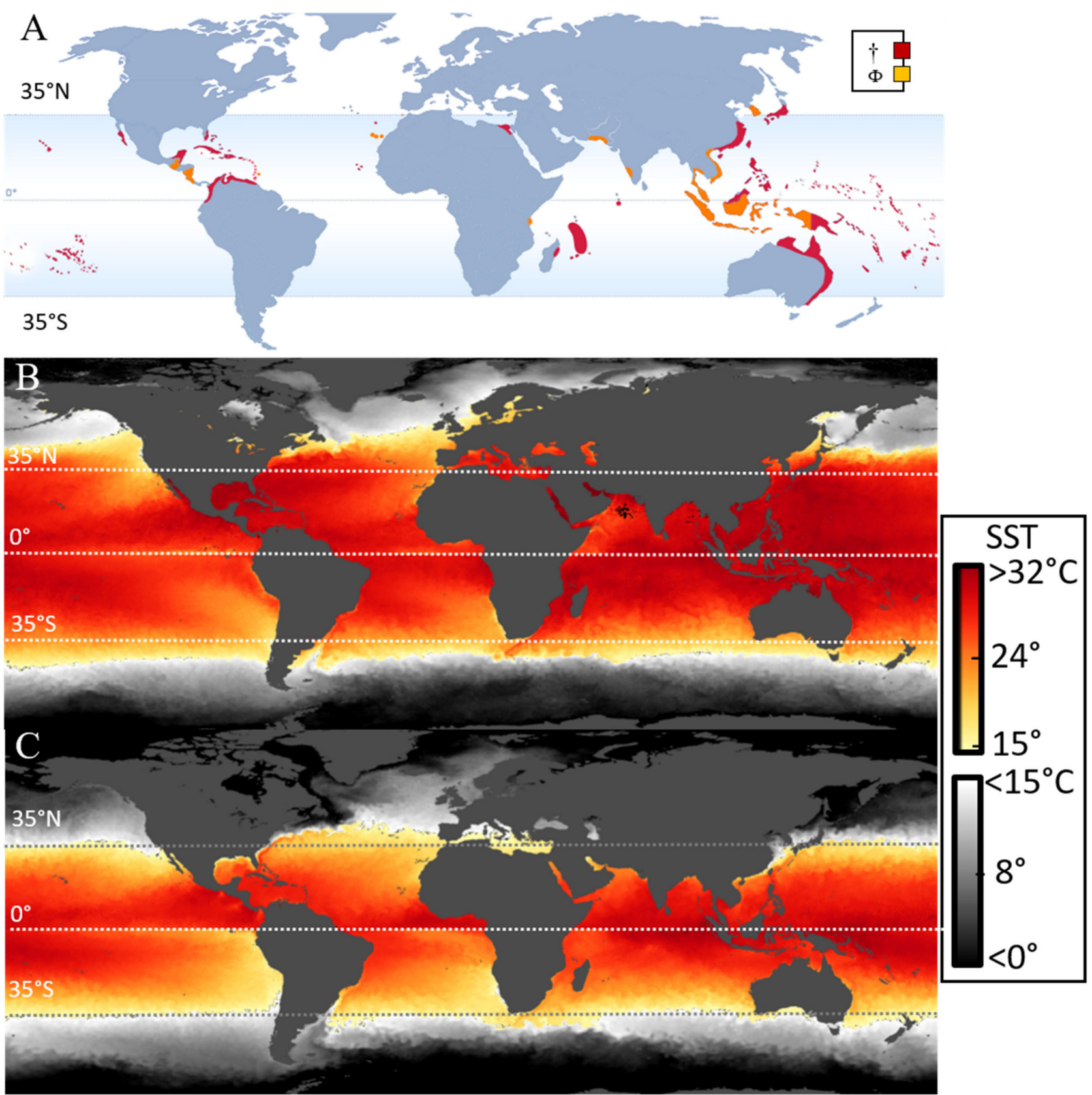

Figure 2. Global map of endemic areas for ciguatera poisoning and satellite-derived sea surface temperatures (SST) divided into two scales, $<15{ }^{\circ} \mathrm{C}$ and $\geq 15{ }^{\circ} \mathrm{C}$. (A) map from https://www.ciguatera.pf/index.php/en/la-ciguatera/ciguateradistribution (accessed on 15 March 2021) and (reproduced with permission from @ Louis Malardé Institute 2020) showing † areas with indigenous ciguatera cases reported and $\phi$ areas with indigenous ciguatera cases reported since 2000. (B) Satellitederived average SST for the most recent peak month of summer in the northern (projection: https://go.nasa.gov/3m1rVhW (accessed on 15 March 2021)) and southern (projection: https://go.nasa.gov/35X8Vvp (accessed on 15 March 2021)) hemisphere, combined. (C) Satellite-derived average SST for the most recent peak month of winter in the northern (February 2020) and southern (August 2020) hemisphere, combined. Gray scale temperature map encompasses the temperatures $<15{ }^{\circ} \mathrm{C}$. Red scale color palette is from 15 to $\geq 32{ }^{\circ} \mathrm{C}$. Satellite SST data generated from the NASA Worldview National Atmospheric and Space Agency's EOSDIS Worldview app, version 3.8.2. Geostationary imagery layers generated from the following sources [56-59].

The burden of identifying the problem, mitigating the risk, and creating a strategy for reducing the incidence of ciguatera primarily falls upon resource and human health managers $[10,16,60-62]$. Numerous countries combating CP around the world 
have implemented domestic policies, like regulating the sale or capture of products implicated in poisonings, such as fish, by size, species, and region, with varying degrees of success $[10,12,14,60,63-65]$. However, domestic solutions are insufficient for this transnational global seafood-related human health problem. A problem that necessitates a multidisciplinary effort involving scientists, consumers, governments, human health experts, and fishers; working together with a dedicated approach for capacity building, willingness to provide technology and knowledge transfer and to share research material to truly address the remaining challenges of $\mathrm{CP}[11,16,66-71]$.

\subsection{Toxin Production}

Currently, 18 species of Gambierdiscus and 3 of Fukuyoa are described [16,72], exhibiting differences (within- and among-species) in toxicity and compound production [29,73-81]. Of these, only a few species (i.e., F. paulensis [82], G. australes [83], G. toxicus [19,83,84], G. polynesiensis $[20,78,81,85])$ have thus far been documented to produce significant amounts of CTXs (CTX3B, -3C, -4A, -4B, 2-OH-CTX3C, M-Seco-CTX3C). Other species capable of producing CTXs have been suggested, but not confirmed. The species identification of collected microalgae isolates was accomplished using phycological techniques and targeted molecular approaches (e.g., fluorescence in-situ hybridization probes, restriction fragment length polymorphism typing, high throughput sequencing metabarcoding, or polymerase chain reaction) [79,86-97]. Field and culture studies identified several factors influencing cell abundance and species distribution, both spatially and temporally. These factors include physical oceanographic properties (e.g., irradiance, wave power, depth, salinity, and temperature), biological (predation, direct and indirect disturbances), and anthropogenic drivers (habitat modification, pollution, and fishing practices) [10,15,98-103]. In culture, Gambierdiscus has displayed inter- and intra-species variability for growth, morphology, and quali-quantitative toxin profile [83,104], which can be influenced by capture location, culture parameters, and time spent in culture (phycological drift) [20,73-75,104-108]. Interactions between bacterial or other microbial co-inhabitants and Gambierdiscus indicated antagonism, competition, or benefits with impacts on fitness and bi-directional regulation in compound production [109-111]. From the perspective of the algae, it remains undescribed whether CTXs, MTXs, and other known compounds (e.g., gambierone, gambieric acids) are produced for inter- or intra-species defense or benefit. Due to the variability within and among species, estimating the toxin content (quantity or type) of a given area based on a knowledge of microalgal species presence/absence/ratio or abundance, without knowing if in-situ cell counts translate into higher toxin ingestion rates of fish, renders seafood safety prediction, based on cell counts, unreliable (at present).

Historically, there were three families of CTXs described, whose chemical structure was labeled loosely based on their geographic origin, namely Caribbean Sea (C-CTXs), Pacific Ocean (P-CTXs), and Indian Ocean (I-CTXs). Although these region-specific descriptions are still in use, the FAO and WHO 'Report of the expert meeting on ciguatera poisoning' recommends a description based upon known chemical structures and geographical distribution. For this adapted approach CTXs, and their derivatives (which include $>30$ analogues) were classified into four separate groups: CTX4A, CTX3C, C-CTX (Caribbean ciguatoxin), I-CTX (Indian ciguatoxin) as summarized by the FAO \& WHO [16], and the references therein. Several questions regarding the structural elucidation of I-CTXs and the microalgal origins of I- and C-CTXs remain unresolved. Toxicity equivalency was investigated for successfully isolated CTXs (of variable purity); however, only CTX3C and CTX1B are commercially available (manufacturer: FUJIFILM Wako Chemicals Europe GmbH (Europe Office) Neuss, Germany, as of February 2021). Therefore, as new commercial sources of standards become available, from certified producers with verified purity, accurate toxicity equivalency should be reassessed [52,112-114]. 


\subsection{CTX Vectors}

Trophically, microalgae are situated at the base of the food web. When the algae are consumed, their toxin contents can be biotransformed and can bioaccumulate in complex multi-directional pathways throughout the food web [36,41,101,115-117]. Therefore, with improvements in detection sensitivity and better insights, it is likely to be proven that most (if not all) species feeding in hyperendemic $\mathrm{CP}$ regions accumulate CTXs, at some point in their life history to some degree. Consumer-resource interactions are a core factor in the transfer of CTXs, where different feeding mechanisms including detritivores, herbivores, planktivores, omnivores, invertivores, and piscivores are involved in the bioaccumulation and transfer of CTXs. CTX profiles in animals are region and species-specific, reflecting a behavior or consumption pattern descriptive of how they acquire CTXs $[35,36,118]$. The modification of CTXs from the less oxidized algal metabolites (e.g., CTX3C, CTX4A/4B) into the highly oxidized (and higher potency) analogs found in fish at higher trophic levels (e.g., CTX4A/B into CTX1B), are associated with (and potentially require) a pathwayspecific to animal metabolism or metabolic transformation [41]. This pathway is not always linear, but generally, fish and shellfish that feed on low trophic level species are associated with containing mainly the algal specific compounds (the less oxidized forms/lower toxic potency) $[35,119]$. Each species individual traits (e.g., home range/distances traveled, feeding mechanism [120], size, prey selection/hunting behavior [121], lifecycle [122]), and even the prey available in the season [123], determine where and how fish feed and, consequently, influence diet and ultimately fish's CTX profile $[124,125]$. Therefore, the feeding mechanisms and unique traits for each species present an opportunity to correlate CTX congener analysis with species, behaviors, or regions (similar to using naturally occurring stable isotopes to answer many of these environmental/nutritional/biological/ecological questions). For example, many species begin life in a nursery-type habitat (e.g., mangroves or seagrass beds), where they hunt small prey (e.g., crustaceans and plankton) [126]. As fish grow and mature, they often undergo an ontogenetic diet shift moving towards locations or habitats (e.g., deep shelf, coral reef) where they may source food that can have a higher total body CTX content (i.e., size as an indicator for prey selection). Inter-annual or seasonal spawning areas and migration routes can contain staging areas, courtship areas, or temporary locations to source food where CTX accumulation can occur [127-130]. These mixed-use and seasonal movements are becoming better understood, but can still lead to complications for historical CTX predictions and associations. CTX contamination seemingly occurs in food webs sporadically $[44,131,132]$. Not all fish within a given reef or common catch area contain CTXs, and fish caught shoaling or schooling together can vary greatly in their CTX content, creating temporal and spatial prediction uncertainties [10,44,64,131,133].

After ingestion, CTXs are metabolized in different ways, subject to the animal's individual biochemical/biological/physiological processes. Generally, CTXs are taken up and first detected in the gastrointestinal tract and liver, then eventually transferred to the muscle tissue and throughout the body and skin [134-137]. Studies examining the behavior of fish administered CTXs found both behavioral abnormalities and the absence of impacts $[135,137]$. The application of next-generation sequencing in fish ecotoxicogenomics could help bridge the link between exposure and effects, a benefit for environmental assessments for CTXs as well as assessing risks to fish health $[138,139]$. Available data regarding the absorption efficiency of CTXs from fish feed was approximately $1-6 \%$, where depuration half-life rates were tissue-related, from several days for the liver to several months in the skin [134]. Within the fish reside many useful biological data points for gaining insight into CTX accumulation, including age (through otolith analysis), dietary shifts due to prey availability or ontogeny (stable isotopic analysis to determine trophic feeding level, location, or habitat utilization type), fish prey information (analysis of gut contents) [140], fish size (by standard morphometrics), fecundity by egg production/weight (impact of CTXs on fish reproduction), and the liver/viscera/brain for bioaccumulation and metabolism data. Correlating these data to the measured CTX burden ultimately provides insights into $\mathrm{CP}$. Future monitoring efforts for these data sources could provide past (CTXs/skin), present 
(CTXs/flesh), and future (CTXs/liver) temporal stages of CTX progression through the localized food web, together with data obtained for Gambierdiscus (CTXs/cell, cells/area). Testing vectors of CTXs, while understanding their behavior, lifecycle, and movement patterns, will help to provide insight into the trophic transfer of CTXs and potentially constrain areas of $\mathrm{CP}$ concern, spatially and temporally, to protect consumers.

Some species are locally considered 'safe for consumption' [141]. However, species implicated in $\mathrm{CP}$ can have wide geographical ranges, e.g., the Nassau grouper (Epinephelus striatus) transcend the jurisdictions of 43 nations or territories [142], or have a relatively small spatial home and hunting ranges, with occasional sporadic movements for spawning aggregations and migrations. Consumer avoidance of $\mathrm{CP}$ risk species can become complicated when identifiable characteristics used for phenotypically determining a species, like the head or skin, are removed during processing [143,144] or when species hybridize [145]. Therefore, the policies guiding CP harvest restrictions can be subverted by deliberate or inadvertent species substitution [146], or by falsifying capture location information [147]. However, sole reliance on previous experience with $\mathrm{CP}$, without updated information, can also be problematic, particularly when climate change is projected to affect the behavior and life cycles of fish leading to new and potentially unforeseen consequences [148-152].

The world's oceans have absorbed heat and $\mathrm{CO}_{2}$ associated with climate change. Excess heat affects the oxygen content of water, which in turn increases the metabolic costs associated with breathing, resulting in changes to behavior, metabolism, respiration, body size, and the life history of fish [152-158]. In the US Virgin Islands (a hyperendemic region for (P), herbivorous fish were observed taking 20,000-156,000 bites $\mathrm{m}^{2} \mathrm{~d}^{-1}$ [159]. Gambierdiscus abundance on algae can range from 1-1,000,000 cells $\mathrm{g}^{-1}$ wet weight of algae [160] and toxin content per cell can exceed a 1000-fold difference between the least and most toxic species [74]. Therefore, any increase in metabolism, due to a lower oxygen content or higher temperature, could result in a higher cell (toxin) ingestion rate. Rising $\mathrm{CO}_{2}$ concentration in the ocean has resulted in ocean acidification (Figure 1). Calcium carbonate dissolves in acidic conditions, therefore a lower $\mathrm{pH}$ in the ocean will impede the calcification process for shell-forming organisms (e.g., shellfish, corals), and even have an impact on fish behavior. A state shift in the coral ecosystem via loss of coral or shellfish bed structural habitat would benefit turf or macroalgae, a preferred habitat for $\mathrm{CP}$ producing microalgae and food source for herbivores. Additionally, climate influences the movement of animals [125,161,162], and better insight into the spaces utilized, movement, and connectivity [163] is desired to make informed decisions concerning how these changes impact the required risk management of $\mathrm{CP}$ and subsequent policies.

\subsection{Human Health: Ciguatera Diagnosis, Epidemiology, and Traceback Investigation}

Challenges to fully understanding the $\mathrm{CP}$ impacts on humans are numerous and include: (i) difficulties in identification and misdiagnosis due to diverse unspecific symptomology (e.g., gastrointestinal, neurologic, and cardiac) [143], (ii) severity related to consumption habits (what parts of the animal were eaten and how much) [114], (iii) patient pre-existing conditions or existing CTX body burden, (iv) willingness to seek treatment $[164,165],(v)$ whether the healthcare system considers ciguatera to be a reportable illness [11,166], (vi) globalized intertwined food networks [146,167], and (vii) international trade and travel where the source of illness (traceback) can be difficult to ascertain $[144,168]$. In most $\mathrm{CP}$ incidents, symptoms are mild or self-resolving, a frequently cited reason for underreporting issues related to ciguatera. CTXs have bioaccumulative properties, therefore, the human exposure at low levels over time may represent a potential human health risk and requires further elucidation [169-171]. Furthermore, where ciguatera cases are rare or unheard-of, awareness of the problem is low, even among healthcare workers [172]. Misdiagnosis can be common and clinical registration with the International Classification of Diseases (ICD-10) under code T61.0: 'Ciguatera fish poisoning' or reporting CP cases with emergency department databases, public health, or data curation authorities is not always mandatory. Information from patients, including consumed species (amount and 
parts of fish) and patient personal information (e.g., weight/age/health), are important data for risk assessors, epidemiologists, and managers [11]. Recent advancements in CTX detection efforts in biological samples (blood, urine) provide a clear path towards independent laboratory confirmation of the clinical diagnosis in addition to meal remnant analyses [173,174].

In the early 21st century, there has been a strong consumer trend towards ethical/healthconscious and sustainable diets, based on alternatives to meat-based protein (e.g., vegetarian, vegan, plant-based), mainly due to environmental, health, religious, philosophical, and ethical reasons [175-178]. This outlook on protein source consumption has relevance for improving the accuracy of CP incidence rates, where consumers who abstain from the consumption of fish and fish-based products (entirely or based on region or species) could be excluded or refined for risk assessments, presenting a more accurate representation of the risk group [64,165]. For example, in an area of emerging risk for CP, the United States Florida Department of Health reported an unadjusted annual incidence rate of 0.2 reports of CP per 100,000 people, while after adjustment for underreporting and a focus on groups of high CP risk the number was projected to be 2000 times higher (400 per 100,000) [179].

Precautionary consumer protection, through the prevention of hazardous contaminants in food products from reaching the consumer market, is a priority for health and food safety organizations, and these efforts include prevention of CP. The European Union's fisheries and aquaculture products market is among the most valuable worldwide and fish with CTX-group toxins are forbidden from this market [180,181]. However, currently, there is no reliable, cost-effective, commercially available preemptive fish-testing commodity for CTXs [182] to ensure a product is CTX free before reaching the market. Additionally, CTXs and MTXs are undetectable by organoleptic methods and are relatively unaffected by acidic and thermal conditions, limiting typical consumer self-protection food preparation options if a product with CTXs is purchased $[183,184]$. A diagnosis of CP is currently based on a recent history of eating fish, the clinical presentation of $\mathrm{CP}$, and if possible analytical testing of a meal remnant, or if a portion is unavailable, a related lot [185]. So far, a meal remnant analysis remains the best scenario for confirmation of potential poisoning. In trace back instances from CP outbreaks, DNA-barcoding is a critical tool for the identification of the ciguatera-causing species [145,186-193]. Toxin identification, quantification, and DNA barcoding [194] can still be performed on the meal remnant even after cooking, yielding valuable information for cataloging CP events and causative fish species $[114,186,195]$.

Historically, in an artisanal (or traditional/subsistence) fishery, products were consumed close to where they were captured, and anglers sold directly to consumers, incentivizing them to ensure safety and sustainable harvest of the product $[132,133,196]$. With a globalized food distribution network, advanced food processing and preserving techniques, it can be difficult to ascertain the product's history, and any inherent potential risks as these products have a much longer shelf life and no restrictions on distance for distribution. Modern advancements have brought digital solutions to value (product) supply chains to meet these uncertainties, from a supplier, consumer, social, and environmental perspective. For example, efforts to increase fish stock knowledge, seafood traceability and transparency can benefit from novel approaches such as Blockchain [197], Radio Frequency Identification Device tags for product authentication (including species and catch data), applications of machine learning [198], data mining, artificial intelligence, and other digital technologies [199-201]. These methods of digitally-enabled food supply chains can help promote sustainable development goals within the context of the fishing industry, which aims to reward responsible and ethical producers and to discourage illegal or unethically produced seafood products from entering the seafood supply chain [202]. Eventually, as the traceback methods based on these technologies become routine and are coupled with modern testing efforts, these understandings and efforts will begin to support one another. Together they will help accelerate the capabilities to predict: (i) when/where fish containing CTXs are originating from (ii) how / why these products came to contain CTXs, (iii) what CTXs or analogues they contain, specifically in terms of helping to identify Gambierdiscus / Fukuyoa or 
specific regional type toxin profile. Therefore, while these digital technologies are still being implemented, to improve and support the accuracy of epidemiological data regarding $\mathrm{CP}$ vectors and their geographic origin, collection of the location, species, and morphological data via all available methods and sources is desired.

\subsection{Modern Testing and Investigation Capabilities}

The FDA established guidance levels of 0.10 and $0.01 \mathrm{ppb}$ equivalent toxicity in fish for C-CTX1 and CTX1B (CTX4A derivative), respectively. The detection of CTXs at these concentrations in complex matrices, with recoveries between $50-100 \%$ requires appropriate facilities and advanced analytical methodologies [10,60,203-208]. Extraction procedures before testing are variable and often time consuming (up to 3 days). Currently, no chemical protocol for CTX extraction in a biological matrix has been validated, an analytical challenge discussed in the FAO and WHO report [16]. The CTX testing protocols include bioassays (in-vivo and in-vitro), biochemical assays, and chemical assays, each selected based on the user's capabilities, requirements, or intentions [16,209]. Those used for supporting the clinical diagnosis of ciguatera (when a meal remnant is available) include the species identification of a meal remnant through DNA barcoding and the toxin analysis using a two-tiered approach (e.g., The U.S. Food and Drug Administration's (FDA) method outlined in $[11,186,210])$. Generally, toxin analysis includes (i) a semi-quantitative screening method capable of measuring composite toxicity in an action-specific or doseresponse manner [210-219] and (ii) confirmation of CTXs identity either by liquid chromatography tandem-mass spectrometry (LC-MS/MS) or LC coupled to High-Resolution MS (LC-HRMS) [36,85,113,183,186,205,210,220-223]. However, many different methods (including local folk methods $[61,224]$ ) were implemented for the detection of CTXs, as recently reviewed by Pasinszki et al. [225]. Beyond the clinical analysis support, the twotiered methods/protocols (semi-quantification paired with confirmation) are commonly used for the monitoring of $\mathrm{CP}$ risk in the frame of surveillance programs for sample analysis of micro-algae, fish, marine invertebrates, solid-phase adsorption toxin tracking filters, or other artificial surfaces/material with the potential to contain Gambierdiscus/Fukuyoa or CTXs, which have been collected in areas of interest. Currently, no validated or accredited method exists for the routine analysis of CTXs.

Methods employed for the first tier 'screening type' approach improved reliability and sensitivity, and are capable of detecting toxins below the guidance levels. Historically, in-vivo-based methods, while not specific, were widely used for toxicity screening, however, due to various analytical and ethical concerns, alternative methods are preferred $[181,226]$. Most in-vitro-based methods, designed to investigate the neurocellular effects of CTXs using various cell types (mouse, guinea pig, rat, human, etc., as reviewed by L'Herondelle et al. [227], and references therein), require the use of a protein-based serum and the use of essential supplements in cell culture. These supplements are mainly animalbased (e.g., fetal bovine serum), which also raises the scientific reliability/repeatability and animal-based ethical concerns of in-vivo methods. Therefore, the design of cell lines that are serum-free/reduced [228] and suitable for a variety of applications are desired; and currently available for some cell lines and in certain instances [229-232]. Further cell line modifications to improve the sensitivity/specificity/ease of use/reliability could benefit from the advent of Clustered Regularly Interspaced Short Palindromic Repeats (CRISPR), CRISPR-associated protein (Cas9), and its subsequent refinements, which can now make genome editing for a better understanding of the genetic basis for observations possible [233-239]. This enables the potential to modify the genome of a cell line, or even algal culture, utilizing a loss-of-function or gain-of-function mutation. For example, this technique has been/can and will be used for genes that encode the various voltage-gated sodium or potassium channels (e.g., knocking-out, increasing, or reducing channel function to tailor a cell line for a specific mode of action or sensitivity). Furthermore, those techniques can be used for the targeting of genes that can up- or down-regulate the toxin (or another compound of choice) production of cultured microalgae or of genes that help 
to adapt a species to survive the conditions suitable for culture (allowing further investigations). This can also become an important tool for investigating marine biotoxins (e.g., CTXs, brevetoxins, and tetrodotoxins), which have variable affinities to a variety of voltage-gated sodium channels that require further elucidation [240-246].

Other efforts to understand the function and processes of cells can benefit from various genomic, proteomic, metabolomic, transcriptomic, and glycomic approaches (OMIC's) to elucidate a diverse array of cellular processes with relevance for drug discovery, food safety [247], method development, and toxins research [248-251]. Recent advances in the development of monoclonal antibodies, specific against CTX1B, 54-deoxyCTX1B, CTX3C, and 51-hydroxyCTX3C have been achieved [252-254]. The availability of monoclonal antibodies was instrumental in the development of sensitive enzyme-linked immunosorbent assays [214,215,255-257], magnetic bead-based immunoassays, and immunosensors $[216,258,259]$. Specific and robust antibodies are needed to develop lateral-flow assays, which are simple, low cost, and with field deployment potential [260]. The design of a lateral-flow assay can be tailored for the analysis of cells, toxins, or genetic material [261]. Additional immunosensing tools (colorimetric immunoassay and electrochemical immunosensors) are available to screen for specific CTXs and genetic information for species identification [216,258]. For observing and measuring cells, microscopy presents a tool commonly used that remained relatively unchanged for decades, however, digitalization has led to rapidly increasing imaging resolution and portability (two desired performance demands), even moving away from refractive lenses in conventional optical settings, enabling ultra-thin, ultralight, and flat imaging systems [260]. Super-resolution imaging of structures in three dimensions at the nanometer-scale $[262,263]$ and high-resolution live cell Raman images can further elucidate many of the questions regarding marine toxin site binding, affinity, and intercellular impacts [264,265].

Among analytical techniques suitable for tier two 'confirmation', LC-MS/MS is the most utilized for the qualitative (and at times quantitative) determination of CTX analogs due to its capacity for high selectivity and sensitivity in detecting analytes at sub-ppb levels in complex matrices [204,225]. The full implementation of LC-MS methods requires sufficient materials (toxins in natural matrices, reference materials, and analytical standards): (i) to optimize analyte ionization and fragmentation settings, to increase sensitivity for reaching the sub-ppb detection levels required, (ii) to chromatographically resolve different structural analogs (of which there are $>30$ ), and (iii) to test the applicability of the method on naturally contaminated and/or spiked samples for method validation (a point that also applies to the tier-one screening methods). Challenges for LC-MS method development stem from the laboratory's LC-MS instrument platforms utilized, including different electrospray ionization source geometries, which can influence the ionization behavior and ultimately detection. The vision of transportable, handheld, miniaturized mass spectrometers for on-site food safety testing is becoming a reality for a variety of applications, with a wide range of molecular weights and polarities being demonstrated [266-268]. However, regardless of the method type, the availability of CTX certified standards or reference materials remains a crucial impediment to method development. Several CTX reference materials have been reported in the literature, generated from naturally incurred material, however, their availability is private and shared among researchers only as gifts or private purchases. Only two CTX congeners, CTX3C and CTX1B, are now commercially available (manufacturer: FUJIFILM Wako Chemicals Europe GmbH (Europe Office) Neuss, Germany, as of February 2021). The availability of authentic analytical standards will aid the improvement of detection and sensitivity capabilities [269,270], which will continue to benefit consumers at risk of chronic low dose exposure to CTXs with the final aim of the inter-laboratory validation of the MS-based methods [271]. This goal of inter-laboratory validation also applies to tier-one screening methods (CBA-N2a, RBA, ELISA, etc.). However, all methods are subject to uncertainties, e.g., insufficient cleanup, matrix suppression, method execution errors, misinterpreted data. Therefore, improving selectivity, sensitivity, repeatability, and reproducibility for CTX quantification in methods is necessary. Together 
these established, improved, and novel methods provide a wide range of options suitable for a method to detect CTXs (and MTXs), with varying degrees of difficulty for implementation. Therefore, different laboratories with a range of capabilities and infrastructure can select the screening type method sufficient for their infrastructure and purpose.

\subsection{Anthropogenic Impacts}

Humans are (inadvertently) exerting influence on the production and distribution of CTXs through changes to the presence, absence, and abundance of toxin-producing species, their vectors, and habitat. Changes in land use and hydrology (impervious surfaces, breakwaters, clearing vegetation, sediment, and freshwater runoff), poor water quality (pollution, hypoxic zones due to excess nutrients $\mathrm{N}, \mathrm{P}, \mathrm{K}$ ), benthic habitat coverage, climate change, overfishing, and the introduction of invasive species can all alter food-web dynamics and CTXs in directions that are uncertain and can lead to non-linear impacts. Ocean warming during the last century has enabled tropical species, including Gambierdiscus, to expand their range poleward [48,272]. A rise in global sea level (approx. 1.7-3.2 $\mathrm{mm} \mathrm{yr}^{-1}$ ) is converting landmass into new shallow water habitat, with a significant acceleration in the rate of sea-level rise predicted for the 21st century [273,274]. Gambierdiscus are forecast to benefit from these environmental changes $[51,275,276]$, as they can tolerate a wide range of light intensities and depths $(<1$ to $150 \mathrm{~m}$ ) [17]. Efforts to predict these impacts can utilize elevation-based assessment models that show digitally where newly submerged areas are likely to provide additional habitat to colonize for adjacent populations of Gambierdiscus in CP endemic areas $[98,132,277]$. Benthic habitat alterations due to natural and anthropogenic causes (e.g., coral bleaching [278,279], reef submersion due to sea-level rise, dredging, boat anchor scarring, loss of mangrove coverage) can alter the wave dampening and storm surge protection provided by natural habitats, further eroding the shoreline for oceanic submersion and creating newly available habitat for Gambierdiscus to colonize [280-283]. Common structural habitats for Gambierdiscus are macro- and turf algae, and changes in benthic habitat type from coral to algae [284-286] (e.g., decrease in ocean pH), or newly submerged habitat converted to macro- and turf algae cover can enhance the proliferation of Gambierdiscus [99,287-290]. A healthy grazer community keeps algal growth in check and excluding grazers (either by overfishing or physical exclusion) can throw off this balance and lead to an increase in Gambierdiscus abundance [98,291,292]. As oceans absorb more $\mathrm{CO}_{2}$, this may benefit algae and seagrasses, as carbon dioxide is required for photosynthesis aiding algal growth rates. Gambierdiscus are historically/currently regionspecific $[160,293]$ and the toxins they produce are used as regional profiles or biomarkers helping to identify the ocean of origin when investigating meal remnant samples from $\mathrm{CP}$ outbreaks. If these region-specific algae are transferred to non-native habitats (e.g., via marine litter [294,295], ballast water [296], accidental introduction) detection methods using the region-specific CTX biomarkers would become invalid as a traceback tool [36], concurrent with human health consequences [36]. Symptoms of CP originating in the region of the Pacific Ocean are primarily described as neurological, while gastrointestinal symptoms dominate the description in the Atlantic/Caribbean [183,297-302]. Therefore, if these species become invasive the region-specific symptomology may become unreliable. In culture, some Gambierdiscus species can respond to an environmental shock (e.g., sudden drop in temperature) by increasing toxin production [303] or loss in toxin production when transferred to a new light environment [304]. When species are introduced to a new environment (e.g., with seasonal cold upwelling), the exposure to novel conditions could result in behavior and responses that are uncharacteristic or unpredictable. Warming waters, size-selective fishing, and overfishing can alter the size structure of fish stocks toward smaller individuals, leading to ecosystem impacts that are diverse and extensive [305]. A decrease in length affects species interactions, biomass, fisheries yield (affecting food security), and ultimately results in unknown (and difficult to track) changes to food web pathways for CTXs [306,307]. The introduction of invasive species can elicit sweeping 
changes to food web dynamics [308-310], benthic cover [311], and invasive fish predators can become novel or dominant CTX vectors and ultimately CP sources [312-315].

Habitat loss, overfishing, invasive species competition, or long-term changes such as ocean acidification and climate change are serious anthropogenic threats to reef fish populations and the overall health of reef ecosystems. Their subsequent short and long-term impacts on CP incidences remain unknown. A pragmatic approach currently employed to mitigate human impacts on marine systems and to increase fisheries productivity [316] is to manage the fishery through various efforts such as the establishment of marine protected areas, or 'no-take' zones [317-319]. Harvest restrictions and marine reserves can also be a useful tool for protecting consumers from the consumption of CTX contaminated fish. However, CTX distribution can be geospatially complex and harvesting at the 'spillover' borders of these protected areas (if they are not sufficiently large) $[127,319,320]$ can potentially carry an increased CP risk [44,132].

Climate change and the global response [321] can have unintended impacts on harmful algal species. To lower greenhouse gas emissions, various studies proposed offshore wind farms for sustainable energy generation; however, Gambierdiscus have been shown to inhabit such novel shallow water structures as demonstrated for oil platforms [322]. Other marine structures created to protect the shoreline from sea-level rise and erosion (e.g., artificial breakwaters, seawalls) can serve as 'artificial reefs' attracting a variety of marine life, which in turn are targeted by fishing communities [323,324]. These artificial reef-type breakwaters and barriers are designed to alter the wave energy approaching the coast [325-327]. Calm, low hydrodynamic habitats can benefit Gambierdiscus [102], therefore, anthropogenic marine modifications can have several impacts on CP. For instance, they could serve as habitat enhancers for CTX producing species, either through shallow water habitat 'stepping-stones', novel hard bottom to adhere, or by reducing ocean wave energy, or serving as fish aggregates modifying where CTXs enter the consumer-resource system. Consequently, their impact on $\mathrm{CP}$ should be monitored.

Globally, communities in the 21st century have demanded and enacted large social and environmental changes over the 'business-as-usual'. This includes the 1995 Kyoto Declaration and Plan of Action to respect the resources, food security, social and economic development of developing countries (in particular small-island developing states) [328]. Additionally, the Nagoya Protocol on access to genetic resources and the fair and equitable sharing of benefits arising from their utilization set forth a framework for protection, as a reaffirmation of the sovereign rights of states to protect their natural resources and traditional knowledge $[329,330]$. Therefore, keeping with this progress it is important for $\mathrm{CP}$-related research efforts to join these goals by striving to meet these standards. Ethical and conservation implications for both human (local indigenous peoples) and ecological communities should be ingrained in the research and their outcomes [331], particularly through ensuring equal partnerships in research and data sharing with local communities, while striving to minimize the ecological impact and reduction in harm to animals during sample collection (when necessary) [332-335].

\subsection{Outlook- Risks and Opportunities}

Increased awareness and efforts studying the intricacies of Gambierdiscus, CTXs, and $\mathrm{CP}$ have led to discoveries at an ever-increasing frequency for each step of the ciguatera problem from the toxin sources to the patients. Improvements in methodology and CTX detection sensitivity are enabling the early discovery of Gambierdiscus and CTXs in locations at the forefront of their expansion, while cell abundance and toxin levels are low. These monitoring efforts are constantly being refined as new physical oceanographic data (e.g., newly launched Sentinel-6 Michael Freilich ocean tracking satellite replacing low-resolution with higher resolution satellite observations), experience from fisheries scientists, CTX method research, food web transmission, and epidemiology surveillance data become available [132,297,336,337]. Further improvements to sample collection precision for Gambierdiscus can also benefit from the adoption of successful protocols, outreach 
(educational material) [301], and coordination efforts currently in use for monitoring other harmful algae species (where appropriate) $[69,338,339]$. The combined efforts of testing accuracy (e.g., species specificity and abundance) and routine-analytics for CTXs will contribute to refined surveillance data accuracy. These improvements are required to 'catch up' to the technology available for developing environmental (remote) biosensors for sensing Gambierdiscus and CTXs in situ. The acquisition of accurate CP-relevant data in near real-time is invaluable information for the design and testing of environmental predictor models, which marine and terrestrial spatial planners rely on to make informed decisions for mitigating $\mathrm{CP}$.

The structures of a variety of marine natural toxins are currently established; however, the biosynthesis of many of these compounds remains unknown. Understanding the natural assembly of these toxins can benefit many research fields, including the potential for producing drug candidates or enhanced toxin detection. For example, Brunson et al. [340] used a multidisciplinary approach, where a breakthrough in the understanding of the biosynthetic pathway led to the expression of the involved genes in bacteria and yeast, resulting in the production and elucidation of a domoic acid isomer. The chemical synthesis of CTXs [269,270,341-344], gambierol [345], gambieric acids [345-347], and MTXs remains challenging [348]. Harvesting of microalgal biomass and large-scale culturing for purification of CTXs and MTXs continues to be an important process towards providing the necessary toxin amounts for full structural characterization and production of (certified) reference materials [16]. With sufficient material available, novel therapeutic applications can be explored by the pharmaceutical industry for new drug development based on the unique affinity for CTXs on mammalian sodium channels [349,350] or MTXs for the study of calcium channel-dependent processes, innate immune response, and physiology of inflammatory effector cells [351]. Moreover, sufficient amounts of microalgal material would allow investigations into the presence of a variety of large molecules, middle molecular-weight compounds, and natural products for bioorganic/biochemical research [352].

\section{Conclusions}

The examples of interdisciplinary cooperation and continued efforts (e.g., EuroCigua project) outlined in this review will continue to drive the efforts for combating $\mathrm{CP}$ towards the prediction of ciguatera in humans and the generation and movement of CTXs in the environment. Understanding these processes from toxin generation and transmission to human health impacts will continue to create benefits for society, in often unforeseen ways, i.e., via environmental protections and informed fishing decisions, the generation and exploration of compounds for beneficial purposes, and ultimately for ensuring a more safe and secure food supply.

Author Contributions: Conceptualization- C.R.L. Writing—: C.R.L., L.T., M.F., A.S., O.K., D.B. all contributed equally to the original draft preparation, review, and editing. All authors have read and agreed to the published version of the manuscript.

Funding: This research received no external funding.

Institutional Review Board Statement: Not applicable.

Informed Consent Statement: Not applicable.

Data Availability Statement: No new data were created or analyzed in this study. Data sharing is not applicable to this article.

Conflicts of Interest: The authors declare no conflict of interest.

\section{References}

1. World Economic Forum. The Global Risks Report 2020. In World Economic Forum, Geneva, Switzerland, Insight Report; World Economic Forum: Cologny/Geneva, Switzerland, 2020.

2. Glibert, P.M.; Burford, M.A. Globally changing nutrient loads and harmful algal blooms: Recent advances, new paradigms, and continuing challenges. Oceanography 2017, 30, 58-69. [CrossRef] 
3. IPCC. Global Warming of $1.5^{\circ} \mathrm{C}$. An IPCC Special Report on the Impacts of Global Warming of $1.5^{\circ} \mathrm{C}$ Above Pre-Industrial Levels and Related Global Greenhouse Gas Emission Pathways, in the Context of Strengthening the Global Response to the Threat of Climate Change, Sustainable Development, and Efforts to Eradicate Poverty; Intergovernmental Panel on Climate Change: Geneva, Switzerland, 2018.

4. Bindoff, N.; Cheung, W.W.; Kairo, J.; Arstegui, J.; Guinder, V.; Hallberg, R.; Hilmi, N.; Jiao, N.; Karim, M.; Levin, L.; et al. Changing ocean, marine ecosystems, and dependent communities. In IPCC Special Report on the Ocean and Cryosphere in a Changing Climate Pörtner, D.C.R.H.-O., Masson-Delmotte, V., Zhai, P., Tignor, M., Poloczanska, E., Mintenbeck, K., Alegría, A., Nicolai, A.O.M., Petzold, J., Rama, B., et al., Eds.; IPCC: Geneva, Switzerland, 2019; in press.

5. FAO. The State of World Fisheries and Aquaculture; Fisheries Department Food and Agriculture Organization of the United Nations; Food \& Agriculture Organization: Rome, Italy, 2012.

6. Connell, J.; Lowitt, K. Food Security in Small Island States; Springer: Singapore, 2020. [CrossRef]

7. Barnett, J. Dangerous climate change in the Pacific Islands: Food production and food security. Reg. Environ. Chang. 2011, 11, 229-237. [CrossRef]

8. Béné, C.; Macfadyen, G.; Allison, E.H. Increasing the Contribution of Small-Scale Fisheries to Poverty Alleviation and Food Security; Food \& Agriculture Organization: Rome, Italy, 2007.

9. Ghina, F. Sustainable Development in Small Island Developing States. Environ. Dev. Sustain. 2003, 5, 139-165. [CrossRef]

10. U.S. Food Drug Administration. Guidance for Industry: Purchasing Reef Fish Species Associated with the Hazard of Ciguatera Fish Poisoning. Available online: https://www.fda.gov/regulatory-information/search-fda-guidance-documents/guidanceindustry-purchasing-reef-fish-species-associated-hazard-ciguatera-fish-poisoning (accessed on 15 October 2020).

11. Friedman, M.A.; Fernandez, M.; Backer, L.C.; Dickey, R.W.; Bernstein, J.; Schrank, K.; Kibler, S.; Stephan, W.; Gribble, M.O.; Bienfang, P.; et al. An Updated Review of Ciguatera Fish Poisoning: Clinical, Epidemiological, Environmental, and Public Health Management. Mar. Drugs 2017, 15, 72. [CrossRef]

12. Sydney Fish Market. Sydney Fish Market Seafood Handing Guidelines. Available online: https://www.sydneyfishmarket.com. au/Seafood-Trading/Quality/Food-Safety (accessed on 6 October 2020).

13. Skinner, M.P.; Brewer, T.D.; Johnstone, R.; Fleming, L.E.; Lewis, R.J. Ciguatera Fish Poisoning in the Pacific Islands (1998 to 2008). PloS Negl. Trop. Dis. 2011, 5. [CrossRef]

14. Lewis, R.J. Socioeconomic impacts and management ciguatera in the Pacific. Bull. Soc. Pathol. Exot. 1992, 85, 427-434.

15. McCubbin, S.G.; Pearce, T.; Ford, J.D.; Smit, B. Social-ecological change and implications for food security in Funafuti, Tuvalu. Ecol. Soc. 2017, 22. [CrossRef]

16. FAO; WHO. Report of the Expert Meeting on Ciguatera Poisoning; Food Safety and Quality: Rome, Italy, 2018. [CrossRef]

17. Kibler, S.R.; Litaker, R.W.; Holland, W.C.; Vandersea, M.W.; Tester, P.A. Growth of eight Gambierdiscus (Dinophyceae) species: Effects of temperature, salinity and irradiance. Harmful Algae 2012, 19, 1-14. [CrossRef]

18. Xu, Y.; Richlen, M.L.; Liefer, J.D.; Robertson, A.; Kulis, D.; Smith, T.B.; Parsons, M.L.; Anderson, D.M. Influence of Environmental Variables on Gambierdiscus spp.(Dinophyceae) Growth and Distribution. PLoS ONE 2016, 11, e0153197. [CrossRef] [PubMed]

19. Satake, M.; Murata, M.; Yasumoto, T. The structure of CTX3C, a ciguatoxin congener isolated from cultured Gambierdiscus toxicus. Tetrahedron Lett. 1993, 34, 1975-1978. [CrossRef]

20. Chinain, M.; Darius, H.T.; Ung, A.; Cruchet, P.; Wang, Z.; Ponton, D.; Laurent, D.; Pauillac, S. Growth and toxin production in the ciguatera-causing dinoflagellate Gambierdiscus polynesiensis (Dinophyceae) in culture. Toxicon 2010, 56, 739-750. [CrossRef]

21. Satake, M.; Murata, M.; Yasumoto, T. Gambierol: A new toxic polyether compound isolated from the marine dinoflagellate Gambierdiscus toxicus. J. Am. Chem. Soc. 1993, 115, 361-362. [CrossRef]

22. Watanabe, R.; Uchida, H.; Suzuki, T.; Matsushima, R.; Nagae, M.; Toyohara, Y.; Satake, M.; Oshima, Y.; Inoue, A.; Yasumoto, T. Gambieroxide, a novel epoxy polyether compound from the dinoflagellate Gambierdiscus toxicus GTP2 strain. Tetrahedron 2013, 69, 10299-10303. [CrossRef]

23. Morohashi, A.; Satake, M.; Nagai, H.; Oshima, Y.; Yasumoto, T. The Absolute Configuration of Gambieric Acids A-D, Potent Antifungal Polyethers, Isolated from the Marine Dinoflagellate Gambierdiscus toxicus. Tetrahedron 2000, 56, 8995-9001. [CrossRef]

24. Rodríguez, I.; Genta-Jouve, G.; Alfonso, C.; Calabro, K.; Alonso, E.; Sánchez, J.A.; Alfonso, A.; Thomas, O.P.; Botana, L.M. Gambierone, a Ladder-Shaped Polyether from the Dinoflagellate Gambierdiscus belizeanus. Org. Lett. 2015, 17, $2392-2395$. [CrossRef] [PubMed]

25. Murray, J.S.; Nishimura, T.; Finch, S.C.; Rhodes, L.L.; Puddick, J.; Harwood, D.T.; Larsson, M.E.; Doblin, M.A.; Leung, P.; Yan, M.; et al. The role of 44-methylgambierone in ciguatera fish poisoning: Acute toxicity, production by marine microalgae and its potential as a biomarker for Gambierdiscus spp. Harmful Algae 2020, 97, 101853. [CrossRef]

26. Holmes, M.J.; Lewis, R.J. Purification and characterisation of large and small maitotoxins from cultured Gambierdiscus toxicus. Nat. Toxins 1994, 2, 64-72. [CrossRef]

27. Boente-Juncal, A.; Álvarez, M.; Antelo, Á.; Rodríguez, I.; Calabro, K.; Vale, C.; Thomas, O.P.; Botana, L.M. Structure Elucidation and Biological Evaluation of Maitotoxin-3, a Homologue of Gambierone, from Gambierdiscus belizeanus. Toxins 2019, 11, 79. [CrossRef]

28. Murata, M.; Naoki, H.; Iwashita, T.; Matsunaga, S.; Sasaki, M.; Yokoyama, A.; Yasumoto, T. Structure of maitotoxin. J. Am. Chem. Soc. 1993, 115, 2060-2062. [CrossRef]

29. Pisapia, F.; Sibat, M.; Herrenknecht, C.; Lhaute, K.; Gaiani, G.; Ferron, P.-J.; Fessard, V.; Fraga, S.; Nascimento, S.M.; Litaker, R.W.; et al. Maitotoxin-4, a novel MTX analog produced by Gambierdiscus excentricus. Mar. Drugs 2017, 15, 220. [CrossRef] 
30. Murata, M.; Naoki, H.; Matsunaga, S.; Satake, M.; Yasumoto, T. Structure and Partial Stereochemical Assignments for Maitotoxin, the Most Toxic and Largest Natural Non-Biopolymer. J. Am. Chem. Soc. 1994, 116, 7098-7107. [CrossRef]

31. Yokoyama, A.; Murata, M.; Oshima, Y.; Iwashita, T.; Yasumoto, T. Some chemical properties of maitotoxin, a putative calcium channel agonist isolated from a marine dinoflagellate. J. Biochem. 1988, 104, 184-187. [CrossRef]

32. Holmes, M.J.; Lewis, R.J.; Gillespie, N.C. Toxicity of Australian and French Polynesian strains of Gambierdiscus Toxicus (Dinophyceae) grown in culture: Characterization of a new type of maitotoxin. Toxicon 1990, 28, 1159-1172. [CrossRef]

33. Kohli, G.; Papiol, G.; Rhodes, L.; Harwood, D.; Selwood, A.; Jerrett, A. A feeding study to probe the uptake of Maitotoxin by snapper (Pagrus auratus). Harmful Algae 2014, 37, 125-132. [CrossRef]

34. Legrand, A.M.; Fukui, M.; Cruchet, P.; Yasumoto, T. Progress on chemical knowledge of ciguatoxins. Bull. Soc. Pathol. Exot. 1992, 85, 467-469. [PubMed]

35. Yogi, K.; Sakugawa, S.; Oshiro, N.; Ikehara, T.; Sugiyama, K.; Yasumoto, T. Determination of Toxins Involved in Ciguatera Fish Poisoning in the Pacific by LC/MS. J. AOAC Int. 2014, 97, 398-402. [CrossRef]

36. Yogi, K.; Oshiro, N.; Inafuku, Y.; Hirama, M.; Yasumoto, T. Detailed LC-MS/MS Analysis of Ciguatoxins Revealing Distinct Regional and Species Characteristics in Fish and Causative Alga from the Pacific. Anal. Chem. 2011, 83, 8886-8891. [CrossRef]

37. Mak, Y.L.; Wai, T.-C.; Murphy, M.B.; Chan, W.H.; Wu, J.J.; Lam, J.C.; Chan, L.L.; Lam, P.K. Pacific Ciguatoxins in Food Web Components of Coral Reef Systems in the Republic of Kiribati. Environ. Sci. Technol. 2013, 47, 14070-14079. [CrossRef]

38. Chan, W.H.; Mak, Y.L.; Wu, J.J.; Jin, L.; Sit, W.H.; Lam, J.C.W.; Sadovy de Mitcheson, Y.; Chan, L.L.; Lam, P.K.S.; Murphy, M.B. Spatial distribution of ciguateric fish in the Republic of Kiribati. Chemosphere 2011, 84, 117-123. [CrossRef]

39. Pottier, I.; Vernoux, J.P.; Lewis, R.J. Ciguatera fish poisoning in the Caribbean islands and western Atlantic. Rev. Environ. Contam. Toxicol. 2001, 168, 99-141.

40. Lewis, R.J.; Sellin, M.; Poli, M.A.; Norton, R.S.; MacLeod, J.K.; Sheil, M.M. Purification and characterization of ciguatoxins from moray eel (Lycodontis javanicus, Muraenidae). Toxicon 1991, 29, 1115-1127. [CrossRef]

41. Ikehara, T.; Kuniyoshi, K.; Oshiro, N.; Yasumoto, T. Biooxidation of Ciguatoxins Leads to Species-Specific Toxin Profiles. Toxins 2017, 9, 205. [CrossRef] [PubMed]

42. Fusetani, N. Marine toxins: An overview. In Marine Toxins as Research Tools; Springer: Berlin/Heidelberg, Germany, 2009; pp. 1-44.

43. Chinain, M.; Gatti, C.M.i.; Darius, H.T.; Quod, J.P.; Tester, P.A. Ciguatera poisonings: A global review of occurrences and trends. Harmful Algae 2020, 101873. [CrossRef]

44. Chinain, M.; Gatti, C.M.i.; Ung, A.; Cruchet, P.; Revel, T.; Viallon, J.; Sibat, M.; Varney, P.; Laurent, V.; Hess, P.; et al. Evidence for the Range Expansion of Ciguatera in French Polynesia: A Revisit of the 2009 Mass-Poisoning Outbreak in Rapa Island (Australes Archipelago). Toxins 2020, 12, 759. [CrossRef]

45. Zanna, L.; Khatiwala, S.; Gregory, J.M.; Ison, J.; Heimbach, P. Global reconstruction of historical ocean heat storage and transport. Proc. Natl. Acad. Sci. USA 2019, 116, 1126. [CrossRef] [PubMed]

46. Laffoley, D.; Baxter, J.M. Explaining Ocean Warming: Causes, Scale, Effects and Consequences; IUCN: Gland, Switzerland, 2016; p. 456. [CrossRef]

47. Gobler, C.J. Climate Change and Harmful Algal Blooms: Insights and perspective. Harmful Algae 2020, 91, 101731. [CrossRef] [PubMed]

48. Tester, P.A.; Litaker, R.W.; Berdalet, E. Climate change and harmful benthic microalgae. Harmful Algae 2020, 91, 101655. [CrossRef] [PubMed]

49. Hallegraeff, G.M.; Anderson, D.M.; Cembella, A.D. Manual on Harmful Marine Algae; UNESCO: Paris, France, $2003 ;$ p. 794.

50. Perez-Arellano, J.L.; Luzardo, O.P.; Brito, A.P.; Cabrera, M.H.; Zumbado, M.; Carranza, C.; Angel-Moreno, A.; Dickey, R.W.; Boada, L.D. Ciguatera fish poisoning, Canary Islands. Emerg. Infect. Dis. 2005, 11, 1981-1982. [CrossRef]

51. Tester, P.A.; Feldman, R.L.; Nau, A.W.; Kibler, S.R.; Wayne Litaker, R. Ciguatera fish poisoning and sea surface temperatures in the Caribbean Sea and the West Indies. Toxicon 2010, 56, 698-710. [CrossRef] [PubMed]

52. Soliño, L.; Costa, P.R. Global impact of ciguatoxins and ciguatera fish poisoning on fish, fisheries and consumers. Environ. Res. 2020, 182, 109111. [CrossRef] [PubMed]

53. Goater, S.; Derne, B.; Weinstein, P. Critical Issues in the Development of Health Information Systems in Supporting Environmental Health: A Case Study of Ciguatera. Environ. Health Perspect. 2011, 119, 585-590. [CrossRef]

54. Kibler, S.R.; Tester, P.A.; Kunkel, K.E.; Moore, S.K.; Litaker, R.W. Effects of ocean warming on growth and distribution of dinoflagellates associated with ciguatera fish poisoning in the Caribbean. Ecol. Model. 2015, 316, 194-210. [CrossRef]

55. Yalachkov, Y.; Hildner, M.; Polomac, N.; Jahnke, K.; Wagner, M.; Baudrexel, S. Cytotoxic edema affecting distinct fiber tracts in ciguatera fish poisoning. Neurology 2019, 92, 145-147. [CrossRef]

56. Ocean Biology Processing Group. MODIS Terra Level 3 SST Thermal IR Monthly 4km Daytime v2014; NASA Physical Oceanography DAAC: OBPG, Goddard Space Flight Center: Greenbelt, MD, USA, 2015. [CrossRef]

57. Ocean Biology Processing Group. MODIS Aqua Level 3 SST Thermal IR Monthly 4km Daytime v2014. NASA Physical Oceanography DAAC: OBPG, Goddard Space Flight Center: Greenbelt, MD, USA, 2015. [CrossRef]

58. Ocean Biology Processing Group. MODIS Aqua Level 3 SST Thermal IR Monthly 9km Daytime v2014. NASA Physical Oceanography DAAC: OBPG, Goddard Space Flight Center: Greenbelt, MD, USA, 2015. [CrossRef]

59. Australian Bureau Of Meteorology. GHRSST Level 4 GAMSSA_28km Global Foundation Sea Surface Temperature Analysis v1.0 dataset (GDS2); NASA Physical Oceanography DAAC, Australian Bureau of Meteorology: Melbourne, Australia, 2019. [CrossRef] 
60. U.S. Food Drug Administration. Fish and Fishery Products Hazards and Controls Guidance Fourth Edition. March $2020 ;$ p. 498. Available online: https://www.fda.gov/media/80637/download (accessed on 15 October 2020).

61. Chinain, M.; Darius, H.T.; Ung, A.; Fouc, M.T.; Revel, T.; Cruchet, P.; Pauillac, S.; Laurent, D. Ciguatera risk management in French Polynesia: The case study of Raivavae Island (Australes Archipelago). Toxicon 2010, 56, 674-690. [CrossRef]

62. Farrell, H.; Murray, S.; Zammit, A.; Edwards, A. Management of Ciguatoxin Risk in Eastern Australia. Toxins 2017, 9, 367. [CrossRef]

63. Chan, T.Y.K. Ciguatoxic potential of Brown-Marbled Grouper in relation to fish size and geographical origin. Am. J. Trop. Med. Hyg. 2015, 93, 1117-1121. [CrossRef] [PubMed]

64. Quod, J.P.; Turquet, J. Ciguatera in Reunion Island (SW Indian Ocean): Epidemiology and clinical patterns. Toxicon 1996, 34, 779-785. [CrossRef]

65. Díaz-Asencio, L.; Clausing, R.J.; Vandersea, M.; Chamero-Lago, D.; Gómez-Batista, M.; Hernández-Albernas, J.I.; Chomérat, N.; Rojas-Abrahantes, G.; Litaker, R.W.; Tester, P.; et al. Ciguatoxin Occurrence in Food-Web Components of a Cuban Coral Reef Ecosystem: Risk-Assessment Implications. Toxins 2019, 11, 722. [CrossRef]

66. D'Anglada, L.; Gould, C.; Thur, S.; Lape, J.; Backer, L.; Bricker, S.; Clyde, T.; Davis, T.; Dortch, Q.; Duriancik, L.; et al. Harmful Algal Blooms and Hypoxia in the United States: A Report on Interagency Progress and Implementation; National Oceanic and Atmospheric Administration; Department of Commerce: Washington, DC, USA, 2018.

67. BfR. Feed and Food Safety in Times of Global Production and Trade; German Federal Institute for Risk Assessment: Berlin, Germany, 2019. [CrossRef]

68. Berdalet, E.; Banas, N.; Bresnan, E.; Burford, M.A.; Davidson, K.; Gobler, C.J.; Karlson, B.; Kudela, R.; Lim, P.; Mackenzie, L. GlobalHAB (IOC-UNESCO and SCOR): International Coordination for Sound Knowledge of HABs to Manage their Impacts; Oceanography Soc. Inc.: Washington, DC, USA, 2018.

69. Berdalet, E.; Tester, P.A.; Chinain, M.; Fraga, S.; Lemée, R.; Litaker, W.; Penna, A.; Usup, G.; Vila, M.; Zingone, A. Harmful algal blooms in benthic systems: Recent progress and future research. Oceanography 2017, 30, 36-45. [CrossRef]

70. Anderson, D. The Ecology and Oceanography of Harmful Algal Blooms (ECOHAB): A National Research Agenda; Woods Hole Oceanographic Institution: Woods Hole, MA, USA, 1995; p. 66.

71. Kudela, R.M.; Raine, R.; Pitcher, G.C.; Gentien, P.; Berdalet, E.; Enevoldsen, H.; Urban, E. Establishment, Goals, and Legacy of the Global Ecology and Oceanography of Harmful Algal Blooms (GEOHAB) Programme. In Global Ecology and Oceanography of Harmful Algal Blooms; Springer: Berlin/Heidelberg, Germany, 2018; pp. 27-49.

72. Guiry, M.D.; Guiry, G. AlgaeBase. Available online: http://www.algaebase.org/search/genus/detail/?genus_id=45535 (accessed on 6 August 2020).

73. Pisapia, F.; Holland, W.C.; Hardison, D.R.; Litaker, R.W.; Fraga, S.; Nishimura, T.; Adachi, M.; Nguyen-Ngoc, L.; Séchet, V.; Amzil, Z.; et al. Toxicity screening of 13 Gambierdiscus strains using neuro-2a and erythrocyte lysis bioassays. Harmful Algae 2017, 63, 173-183. [CrossRef] [PubMed]

74. Litaker, R.W.; Holland, W.C.; Hardison, D.R.; Pisapia, F.; Hess, P.; Kibler, S.R.; Tester, P.A. Ciguatoxicity of Gambierdiscus and Fukuyoa species from the Caribbean and Gulf of Mexico. PLoS ONE 2017, 12, e0185776. [CrossRef]

75. Tudó, À.; Toldrà, A.; Rey, M.; Todolí, I.; Andree, K.B.; Fernández-Tejedor, M.; Campàs, M.; Sureda, F.X.; Diogène, J. Gambierdiscus and fukuyoa as potential indicators of ciguatera risk in the balearic islands. Harmful Algae 2020, 99, 101913. [CrossRef] [PubMed]

76. Tudó, À.; Gaiani, G.; Varela, M.R.; Tsumuraya, T.; Andree, K.B.; Fernández-Tejedor, M.; Campàs, M.; Diogène, J. Further advance of Gambierdiscus Species in the Canary Islands, with the First Report of Gambierdiscus belizeanus. Toxins 2020, 12, 692. [CrossRef] [PubMed]

77. Larsson, M.; Laczka, O.; Harwood, D.; Lewis, R.; Himaya, S.; Murray, S.; Doblin, M. Toxicology of Gambierdiscus spp. (Dinophyceae) from Tropical and Temperate Australian Waters. Mar. Drugs 2018, 16, 7. [CrossRef]

78. Munday, R.; Murray, S.; Rhodes, L.L.; Larsson, M.E.; Harwood, D.T. Ciguatoxins and Maitotoxins in Extracts of Sixteen Gambierdiscus Isolates and One Fukuyoa Isolate from the South Pacific and Their Toxicity to Mice by Intraperitoneal and Oral Administration. Mar. Drugs 2017, 15, 208. [CrossRef]

79. Chinain, M.; Faust, M.A.; Pauillac, S. Morphology and molecular analyses of three toxic species of Gambierdiscus (Dinophyceae): G. pacificus, sp. nov., G. australes, sp. nov., and G. polynesiensis, sp. nov. J. Phycol. 1999, 35, 1282-1296. [CrossRef]

80. Chinain, M.; Gatti, C.M.; Roué, M.; Darius, H.T. Ciguatera-causing dinoflagellates in the genera Gambierdiscus and Fukuyoa: Distribution, ecophysiology and toxicology. In Dinoflagellates: Morphology, Life History and Ecological Significance; Nova Science Publishers: New York, NY, USA, 2020.

81. Longo, S.; Sibat, M.; Viallon, J.; Darius, H.T.; Hess, P.; Chinain, M. Intraspecific Variability in the Toxin Production and Toxin Profiles of In Vitro Cultures of Gambierdiscus polynesiensis (Dinophyceae) from French Polynesia. Toxins 2019, 11, 735. [CrossRef] [PubMed]

82. Laza-Martinez, A.; David, H.; Riobo, P.; Miguel, I.; Orive, E. Characterization of a Strain of Fukuyoa paulensis (Dinophyceae) from the Western Mediterranean Sea. J. Eukaryot. Microbiol. 2016, 63, 481-497. [CrossRef] [PubMed]

83. Roeder, K.; Erler, K.; Kibler, S.; Tester, P.; Ho, V.T.; Lam, N.N.; Gerdts, G.; Luckas, B. Characteristic profiles of Ciguatera toxins in different strains of Gambierdiscus spp. Toxicon 2010, 56, 731-738. [CrossRef] 
84. Satake, M.; Ishibashi, Y.; Legrand, A.-M.; Yasumoto, T. Isolation and Structure of Ciguatoxin-4A, a New Ciguatoxin Precursor, from Cultures of Dinoflagellate Gambierdiscus toxicus and Parrotfish Scarus gibbus. Biosci. Biotechnol. Biochem. 1996, 60, 2103-2105. [CrossRef]

85. Sibat, M.; Herrenknecht, C.; Darius, H.T.; Roue, M.; Chinain, M.; Hess, P. Detection of pacific ciguatoxins using liquid chromatography coupled to either low or high resolution mass spectrometry (LC-MS/MS). J. Chromatogr. A 2018. [CrossRef] [PubMed]

86. Kretzschmar, A.L.; Verma, A.; Kohli, G.; Murray, S. Development of a quantitative PCR assay for the detection and enumeration of a potentially ciguatoxin-producing dinoflagellate, Gambierdiscus lapillus (Gonyaulacales, Dinophyceae). PLoS ONE 2019, 14, e0224664. [CrossRef] [PubMed]

87. Kretzschmar, A.L.; Verma, A.; Harwood, T.; Hoppenrath, M.; Murray, S. Characterization of Gambierdiscus lapillus sp. nov. (Gonyaulacales, Dinophyceae): A new toxic dinoflagellate from the Great Barrier Reef (Australia). J. Phycol. 2017, 53, 283-297. [CrossRef] [PubMed]

88. Smith, K.F.; Biessy, L.; Argyle, P.A.; Trnski, T.; Halafihi, T.; Rhodes, L.L. Molecular Identification of Gambierdiscus and Fukuyoa (Dinophyceae) from Environmental Samples. Mar. Drugs 2017, 15, 243. [CrossRef] [PubMed]

89. Lyu, Y.; Richlen, M.L.; Sehein, T.R.; Chinain, M.; Adachi, M.; Nishimura, T.; Xu, Y.; Parsons, M.L.; Smith, T.B.; Zheng, T.; et al. LSU rDNA based RFLP assays for the routine identification of Gambierdiscus species. Harmful Algae 2017, 66, 20-28. [CrossRef]

90. Sassenhagen, I.; Erdner, D.L. Microsatellite markers for the dinoflagellate Gambierdiscus caribaeus from high-throughput sequencing data. J. Appl. Phycol. 2017, 29, 1927-1932. [CrossRef]

91. Nishimura, T.; Hariganeya, N.; Tawong, W.; Sakanari, H.; Yamaguchi, H.; Adachi, M. Quantitative PCR assay for detection and enumeration of ciguatera-causing dinoflagellate Gambierdiscus spp. (Gonyaulacales) in coastal areas of Japan. Harmful Algae 2016, 52, 11-22. [CrossRef]

92. Nishimura, T.; Sato, S.; Tawong, W.; Sakanari, H.; Uehara, K.; Shah, M.M.R.; Suda, S.; Yasumoto, T.; Taira, Y.; Yamaguchi, H.; et al. Genetic diversity and distribution of the ciguatera-causing dinoflagellate Gambierdiscus spp. (Dinophyceae) in coastal areas of Japan. PLoS ONE 2013, 8, e60882. [CrossRef]

93. Leung, P.T.Y.; Yan, M.; Lam, V.T.T.; Yiu, S.K.F.; Chen, C.-Y.; Murray, J.S.; Harwood, D.T.; Rhodes, L.L.; Lam, P.K.S.; Wai, T.-C. Phylogeny, morphology and toxicity of benthic dinoflagellates of the genus Fukuyoa (Goniodomataceae, Dinophyceae) from a subtropical reef ecosystem in the South China Sea. Harmful Algae 2018, 74, 78-97. [CrossRef]

94. Gómez, F.; Qiu, D.; Lopes, R.M.; Lin, S. Fukuyoa paulensis gen. et sp. nov., a new genus for the globular species of the dinoflagellate Gambierdiscus (Dinophyceae). PLoS ONE 2015, 10, e0119676. [CrossRef] [PubMed]

95. Vandersea, M.W.; Kibler, S.R.; Holland, W.C.; Tester, P.A.; Schultz, T.F.; Faust, M.A.; Holmes, M.J.; Chinain, M.; Wayne Litaker, R. Development of semi-quantitative pcr assays for the detection and enumeration of gambierdiscus species (gonyaulacales, dinophyceae) 1. J. Phycol. 2012, 48, 902-915. [CrossRef]

96. Fraga, S.; Rodríguez, F. Genus Gambierdiscus in the Canary Islands (NE Atlantic Ocean) with Description of Gambierdiscus silvae sp. nov., a New Potentially Toxic Epiphytic Benthic Dinoflagellate. Protist 2014, 165, 839-853. [CrossRef]

97. Richlen, M.L.; Barber, P.H. A technique for the rapid extraction of microalgal DNA from single live and preserved cells. Mol. Ecol. Notes 2005, 5, 688-691. [CrossRef]

98. Loeffler, C.R.; Richlen, M.L.; Brandt, M.E.; Smith, T.B. Effects of grazing, nutrients, and depth on the ciguatera-causing dinoflagellate Gambierdiscus in the US Virgin Islands. Mar. Ecol. Prog. Ser. 2015, 531, 91-104. [CrossRef]

99. Yasumoto, T.; Inoue, A.; Ochi, T.; Fujimoto, K.; Oshima, Y.; Fukuyo, Y.; Adachi, R.; Bagnis, R. Environmental-studies on a toxic dinoflagellate responsible for ciguatera. Bull. Jpn. Soc. Sci. Fish. 1980, 46, 1397-1404. [CrossRef]

100. Parsons, M.L.; Settlemier, C.J.; Bienfang, P.K. A simple model capable of simulating the population dynamics of Gambierdiscus, the benthic dinoflagellate responsible for ciguatera fish poisoning. Harmful Algae 2010, 10, 71-80. [CrossRef]

101. Chateau-Degat, M.L.; Chinain, M.; Cerf, N.; Gingras, S.; Hubert, B.; Dewailly, E. Seawater temperature, Gambierdiscus spp. variability and incidence of ciguatera poisoning in French Polynesia. Harmful Algae 2005, 4, 1053-1062. [CrossRef]

102. Richlen, M.L.; Lobel, P.S. Effects of depth, habitat, and water motion on the abundance and distribution of ciguatera dinoflagellates at Johnston Atoll, Pacific Ocean. Mar. Ecol. Prog. Ser. 2011, 421, 51-66. [CrossRef]

103. Wedding, L.M.; Lecky, J.; Gove, J.M.; Walecka, H.R.; Donovan, M.K.; Williams, G.J.; Jouffray, J.-B.; Crowder, L.B.; Erickson, A.; Falinski, K. Advancing the integration of spatial data to map human and natural drivers on coral reefs. PLoS ONE 2018, 13, e0189792. [CrossRef] [PubMed]

104. Reverté, L.; Toldrà, A.; Andree, K.B.; Fraga, S.; de Falco, G.; Campàs, M.; Diogène, J. Assessment of cytotoxicity in ten strains of Gambierdiscus australes from Macaronesian Islands by neuro-2a cell-based assays. J. Appl. Phycol. 2018, 30, 2447-2461. [CrossRef]

105. Wu, Z.; Luo, H.; Yu, L.; Lee, W.H.; Li, L.; Mak, Y.L.; Lin, S.; Lam, P.K. Characterizing ciguatoxin (CTX)-and Non-CTX-producing strains of Gambierdiscus balechii using comparative transcriptomics. Sci. Total Environ. 2020, 717, 137184. [CrossRef] [PubMed]

106. Rossignoli, A.E.; Tudó, A.; Bravo, I.; Díaz, P.A.; Diogène, J.; Riobó, P. Toxicity Characterisation of Gambierdiscus Species from the Canary Islands. Toxins 2020, 12, 134. [CrossRef] [PubMed]

107. Rhodes, L.; Harwood, T.; Smith, K.; Argyle, P.; Munday, R. Production of ciguatoxin and maitotoxin by strains of Gambierdiscus australes, G. pacificus and G. polynesiensis (Dinophyceae) isolated from Rarotonga, Cook Islands. Harmful Algae 2014, 39, 185-190. [CrossRef] 
108. Estevez, P.; Sibat, M.; Leão-Martins, J.M.; Tudó, A.; Rambla-Alegre, M.; Aligizaki, K.; Diogène, J.; Gago-Martinez, A.; Hess, P. Use of Mass Spectrometry to Determine the Diversity of Toxins Produced by Gambierdiscus and Fukuyoa Species from Balearic Islands and Crete (Mediterranean Sea) and the Canary Islands (Northeast Atlantic). Toxins 2020, 12, 305. [CrossRef]

109. Rambo, I.M.; Dombrowski, N.; Constant, L.; Erdner, D.; Baker, B.J. Metabolic relationships of uncultured bacteria associated with the microalgae. Gambierdiscus. Environ. Microbiol. 2020, 22, 1764-1783. [CrossRef] [PubMed]

110. Sakami, T.; Nakahara, H.; Chinain, M.; Ishida, Y. Effects of epiphytic bacteria on the growth of the toxic dinoflagellate Gambierdiscus toxicus (Dinophyceae). J. Exp. Mar. Biol. Ecol. 1999, 233, 231-246. [CrossRef]

111. Wang, B.; Yao, M.; Zhou, J.; Tan, S.; Jin, H.; Zhang, F.; Mak, Y.L.; Wu, J.; Lai Chan, L.; Cai, Z. Growth and toxin production of Gambierdiscus spp. can be regulated by quorum-sensing bacteria. Toxins 2018, 10, 257. [CrossRef] [PubMed]

112. Soliño, L.; Costa, P.R. Differential toxin profiles of ciguatoxins in marine organisms: Chemistry, fate and global distribution. Toxicon 2018, 150, 124-143. [CrossRef] [PubMed]

113. Hamilton, B.; Hurbungs, M.; Vernoux, J.P.; Jones, A.; Lewis, R.J. Isolation and characterisation of Indian Ocean ciguatoxin. Toxicon 2002, 40, 685-693. [CrossRef]

114. Diogène, J.; Reverté, L.; Rambla-Alegre, M.; del Río, V.; de la Iglesia, P.; Campàs, M.; Palacios, O.; Flores, C.; Caixach, J.; Ralijaona, C.; et al. Identification of ciguatoxins in a shark involved in a fatal food poisoning in the Indian Ocean. Sci. Rep. 2017, 7, 8240. [CrossRef] [PubMed]

115. Scheuer, P.J.; Takahashi, W.; Tsutsumi, J.; Yoshida, T. Ciguatoxin: Isolation and chemical nature. Science 1967, 155, 1267-1268. [CrossRef] [PubMed]

116. Randall, J.E. A review of ciguatera, tropical fish poisoning, with a tentative explanation of its cause. Bull. Mar. Sci. 1958, 8, 236-267.

117. Banner, A.H.; Scheuer, P.J.; Sasaki, S.; Helfrich, P.; Alender, C.B. Observations on Ciguatera-Type Toxin in Fish. Ann. N. Y. Acad. Sci. 1960, 90, 770-787. [CrossRef] [PubMed]

118. Lewis, R.J.; Holmes, M.J. Origin and Transfer of Toxins Involved in Ciguatera. Comp. Biochem. Physiol. C-Pharmacol. Toxicol. Endocrinol. 1993, 106, 615-628. [CrossRef]

119. Darius, H.; Roué, M.; Sibat, M.; Viallon, J.; Gatti, C.; Vandersea, M.; Tester, P.; Litaker, R.; Amzil, Z.; Hess, P.; et al. Tectus niloticus (Tegulidae, Gastropod) as a Novel Vector of Ciguatera Poisoning: Detection of Pacific Ciguatoxins in Toxic Samples from Nuku Hiva Island (French Polynesia). Toxins 2018, 10, 2. [CrossRef] [PubMed]

120. Munsterman, K.S.; Allgeier, J.E.; Peters, J.R.; Burkepile, D.E. A View From Both Ends: Shifts in Herbivore Assemblages Impact Top-Down and Bottom-Up Processes on Coral Reefs. Ecosystems 2021. [CrossRef]

121. Collins, A.B.; Motta, P.J. A kinematic investigation into the feeding behavior of the Goliath grouper Epinephelus itajara. Environ. Biol. Fish. 2017, 100, 309-323. [CrossRef]

122. Szedlmayer, S.T.; Lee, J.D. Diet shifts of juvenile red snapper (Lutjanus campechanus) with changes in habitat and fish size. Fish. Bull. 2004, 102, 366-375.

123. Zamora-Terol, S.; Novotny, A.; Winder, M. Reconstructing marine plankton food web interactions using DNA metabarcoding. Mol. Ecol. 2020, 29, 3380-3395. [CrossRef] [PubMed]

124. Clifton, K.E. Asynchronous food availability on neighboring Caribbean coral reefs determines seasonal patterns of growth and reproduction for the herbivorous parrotfish Scarus iserti. Mar. Ecol. Prog. Ser. 1995, 116, 39-46. [CrossRef]

125. Holland, M.M.; Smith, J.A.; Everett, J.D.; Vergés, A.; Suthers, I.M. Latitudinal patterns in trophic structure of temperate reefassociated fishes and predicted consequences of climate change. Fish Fish. 2020, 21, 1092-1108. [CrossRef]

126. Randall, J.E. Food Habits of Reef Fishes of the West Indies; Institute of Marine Sciences, University of Miami: Coral Gables, FL, USA, 1967.

127. Pittman, S.J.; Monaco, M.E.; Friedlander, A.M.; Legare, B.; Nemeth, R.S.; Kendall, M.S.; Poti, M.; Clark, R.D.; Wedding, L.M.; Caldow, C. Fish with Chips: Tracking Reef Fish Movements to Evaluate Size and Connectivity of Caribbean Marine Protected Areas. PLoS ONE 2014, 9, e96028. [CrossRef] [PubMed]

128. Nemeth, R.S. Population characteristics of a recovering US Virgin Islands red hind spawning aggregation following protection. Mar. Ecol. Prog. Ser. 2005, 286, 81-97. [CrossRef]

129. Friedlander, A.M.; Monaco, M.E.; Clark, R.; Pittman, S.J.; Beets, J.; Boulon, R.; Callender, R.; Christensen, J.; Hile, S.D.; Kendall, M.S. Fish Movement Patterns in Virgin Islands National Park, Virgin Islands Coral Reef National Monument and Adjacent Waters. NOAA Technical Memorandum NOS NCCOS; NOAA: Silver Spring, MD, USA, 2013; p. 172.

130. Nemeth, R.S. Ecosystem Aspects of Species That Aggregate to Spawn. In Reef Fish Spawning Aggregations: Biology, Research and Management; Sadovy de Mitcheson, Y., Colin, P.L., Eds.; Springer: Dordrecht, The Netherlands, 2012; pp. 21-55. [CrossRef]

131. Oshiro, N.; Tomikawa, T.; Kuniyoshi, K.; Ishikawa, A.; Toyofuku, H.; Kojima, T.; Asakura, H. LC-MS/MS Analysis of Ciguatoxins Revealing the Regional and Species Distinction of Fish in the Tropical Western Pacific. J. Mar. Sci. Eng. 2021, 9, 299. [CrossRef]

132. Loeffler, C.R.; Robertson, A.; Flores Quintana, H.A.; Silander, M.C.; Smith, T.B.; Olsen, D. Ciguatoxin prevalence in 4 commercial fish species along an oceanic exposure gradient in the US Virgin Islands. Environ. Toxicol. Chem. 2018, 37, 1852-1863. [CrossRef]

133. Olsen, D.A.; Nellis, D.W.; Wood, R.S. Ciguatera in the Eastern Caribbean. Mar. Fish. Rev. 1984, 46, 13-18.

134. Li, J.; Mak, Y.L.; Chang, Y.-H.; Xiao, C.; Chen, Y.-M.; Shen, J.; Wang, Q.; Ruan, Y.; Lam, P.K.S. Uptake and Depuration Kinetics of Pacific Ciguatoxins in Orange-Spotted Grouper (Epinephelus coioides). Environ. Sci. Technol. 2020. [CrossRef] 
135. Clausing, R.J.; Losen, B.; Oberhaensli, F.R.; Darius, H.T.; Sibat, M.; Hess, P.; Swarzenski, P.W.; Chinain, M.; Dechraoui Bottein, M.-Y. Experimental evidence of dietary ciguatoxin accumulation in an herbivorous coral reef fish. Aquat. Toxicol. 2018, 200, 257-265. [CrossRef] [PubMed]

136. Roué, M.; Darius, H.; Ung, A.; Viallon, J.; Sibat, M.; Hess, P.; Amzil, Z.; Chinain, M. Tissue Distribution and Elimination of Ciguatoxins in Tridacna maxima (Tridacnidae, Bivalvia) Fed Gambierdiscus polynesiensis. Toxins 2018, 10, 189. [CrossRef] [PubMed]

137. Ledreux, A.; Brand, H.; Chinain, M.; Bottein, M.-Y.D.; Ramsdell, J.S. Dynamics of ciguatoxins from Gambierdiscus polynesiensis in the benthic herbivore Mugil cephalus: Trophic transfer implications. Harmful Algae 2014, 39, 165-174. [CrossRef]

138. Mehinto, A.; Martyniuk, C.; Spade, D.; Denslow, N. Applications for next-generation sequencing in fish ecotoxicogenomics. Front. Genet. 2012, 3, 62. [CrossRef] [PubMed]

139. Miracle, A.L.; Ankley, G.T. Ecotoxicogenomics: Linkages between exposure and effects in assessing risks of aquatic contaminants to fish. Reprod. Toxicol. 2005, 19, 321-326. [CrossRef] [PubMed]

140. Malpica-Cruz, L.; Green, S.J.; Côté, I.M. Temporal and ontogenetic changes in the trophic signature of an invasive marine predator. Hydrobiologia 2019, 839, 71-86. [CrossRef]

141. Froese, R.; Pauly, D. FishBase. Available online: www.fishbase.org (accessed on 20 November 2020).

142. Taylor, J.C.; Karnauskas, M.; Cherubin, L.; Schärer-Umpierre, M.; Michaels, W.L.; Caillouet, R.; Campbell, M.; Demer, D.; Erisman, B.; Fulton, S.; et al. Emerging Science and Technology to Improve Monitoring and Assessments of Fish Spawning Aggregations. Report from the 2019 Gulf and Caribbean Fisheries Institute Workshop. Gulf and Caribbean Fisheries Institute: Overseas Hwy Marathon, FL, USA, 2020; p. 74, NOAA Tech. Memo. NMFS-F/SPO-207.

143. de Haro, L.; Schmitt, C.; Sinno-Tellier, S.; Paret, N.; Boels, D.; Le Roux, G.; Langrand, J.; Delcourt, N.; Labadie, M.; Simon, N. Ciguatera fish poisoning in France: Experience of the French Poison Control Centre Network from 2012 to 2019. Clin. Toxicol. 2020; $1-4$. [CrossRef]

144. Friedemann, M. Ciguatera fish poisoning outbreaks from 2012 to 2017 in Germany caused by snappers from India, Indonesia, and Vietnam. J. Consum. Prot. Food Saf. 2019, 14, 71-80. [CrossRef]

145. Loeffler, C.R.; Handy, S.M.; Flores Quintana, H.A.; Deeds, J.R. Fish hybridization leads to uncertainty regarding ciguatera fish poisoning risk: Confirmation of hybridization and ciguatoxin accumulation with implications for stakeholders. J. Mar. Sci. Eng. 2019, 7, 105. [CrossRef]

146. Kusche, H.; Hanel, R. Consumers of mislabeled tropical fish exhibit increased risks of ciguatera intoxication: A report on substitution patterns in fish imported at Frankfurt Airport, Germany. Food Control 2021, 121, 107647. [CrossRef]

147. Kappel, K.; Schröder, U. Difficulties in DNA barcoding-based authentication of snapper products due to ambiguous nucleotide sequences in public databases. Food Control 2020, 118, 107348. [CrossRef]

148. Bernal, M.A.; Schunter, C.; Lehmann, R.; Lightfoot, D.J.; Allan, B.J.M.; Veilleux, H.D.; Rummer, J.L.; Munday, P.L.; Ravasi, T. Species-specific molecular responses of wild coral reef fishes during a marine heatwave. Sci. Adv. 2020, 6, eaay3423. [CrossRef]

149. Sunday, J.M.; Pecl, G.T.; Frusher, S.; Hobday, A.J.; Hill, N.; Holbrook, N.J.; Edgar, G.J.; Stuart-Smith, R.; Barrett, N.; Wernberg, T. Species traits and climate velocity explain geographic range shifts in an ocean-warming hotspot. Ecol. Lett. 2015, 18, 944-953. [CrossRef] [PubMed]

150. Petitgas, P.; Rijnsdorp, A.D.; Dickey-Collas, M.; Engelhard, G.H.; Peck, M.A.; Pinnegar, J.K.; Drinkwater, K.; Huret, M.; Nash, R.D.M. Impacts of climate change on the complex life cycles of fish. Fish. Oceanogr. 2013, 22, 121-139. [CrossRef]

151. Oliver, E.C.; Donat, M.G.; Burrows, M.T.; Moore, P.J.; Smale, D.A.; Alexander, L.V.; Benthuysen, J.A.; Feng, M.; Gupta, A.S.; Hobday, A.J. Longer and more frequent marine heatwaves over the past century. Nat. Commun. 2018, 9, 1-12. [CrossRef]

152. Holt, R.E.; Jørgensen, C. Climate change in fish: Effects of respiratory constraints on optimal life history and behaviour. Biol. Lett. 2015, 11, 20141032. [CrossRef]

153. Alva-Basurto, J.C.; Arias-González, J.E. Modelling the effects of climate change on a Caribbean coral reef food web. Ecol. Model. 2014, 289, 1-14. [CrossRef]

154. Nilsson, G.E.; Östlund-Nilsson, S.; Munday, P.L. Effects of elevated temperature on coral reef fishes: Loss of hypoxia tolerance and inability to acclimate. Comp. Biochem. Physiol. Part A Mol. Integr. Physiol. 2010, 156, 389-393. [CrossRef] [PubMed]

155. Rummer, J.L.; Couturier, C.S.; Stecyk, J.A.W.; Gardiner, N.M.; Kinch, J.P.; Nilsson, G.E.; Munday, P.L. Life on the edge: Thermal optima for aerobic scope of equatorial reef fishes are close to current day temperatures. Glob. Chang. Biol. 2013. [CrossRef] [PubMed]

156. Sheridan, J.A.; Bickford, D. Shrinking body size as an ecological response to climate change. Nat. Clim. Chang. 2011, 1, 401-406. [CrossRef]

157. Cheung, W.W.L.; Sarmiento, J.L.; Dunne, J.; Frolicher, T.L.; Lam, V.W.Y.; Deng Palomares, M.L.; Watson, R.; Pauly, D. Shrinking of fishes exacerbates impacts of global ocean changes on marine ecosystems. Nat. Clim. Chang. 2013, 3, 254-258. [CrossRef]

158. Doney, S.C.; Ruckelshaus, M.; Duffy, J.E.; Barry, J.P.; Chan, F.; English, C.A.; Galindo, H.M.; Grebmeier, J.M.; Hollowed, A.B.; Knowlton, N.; et al. Climate Change Impacts on Marine Ecosystems. Annu. Rev. Mar. Sci. 2012, 4, 11-37. [CrossRef] [PubMed]

159. Carpenter, R.C. Partitioning herbivory and its effects on coral reef algal communities. Ecol. Monogr. 1986, 56, 345-363. [CrossRef]

160. Litaker, R.W.; Vandersea, M.W.; Faust, M.A.; Kibler, S.R.; Nau, A.W.; Holland, W.C.; Chinain, M.; Holmes, M.J.; Tester, P.A. Global distribution of ciguatera causing dinoflagellates in the genus Gambierdiscus. Toxicon 2010, 56, 711-730. [CrossRef] 
161. Davidson, S.C.; Bohrer, G.; Gurarie, E.; LaPoint, S.; Mahoney, P.J.; Boelman, N.T.; Eitel, J.U.H.; Prugh, L.R.; Vierling, L.A.; Jennewein, J.; et al. Ecological insights from three decades of animal movement tracking across a changing Arctic. Science 2020, 370, 712-715. [CrossRef]

162. Pecl, G.T.; Araújo, M.B.; Bell, J.D.; Blanchard, J.; Bonebrake, T.C.; Chen, I.-C.; Clark, T.D.; Colwell, R.K.; Danielsen, F.; Evengård, B.; et al. Biodiversity redistribution under climate change: Impacts on ecosystems and human well-being. Science 2017, 355, eaai9214. [CrossRef]

163. O'Dor, R.K.; Stokesbury, M.J.W. The Ocean Tracking Network-Adding Marine Animal Movements to the Global Ocean Observing System. In Tagging and Tracking of Marine Animals with Electronic Devices; Nielsen, J.L., Arrizabalaga, H., Fragoso, N., Hobday, A., Lutcavage, M., Sibert, J., Eds.; Springer: Dordrecht, The Netherlands, 2009; pp. 91-100. [CrossRef]

164. Radke, E.; Grattan, L.; Roberts, S.; Abbott, M.; Morris, J.G. Incidence and Awareness of Ciguatera Fish Poisoning in St. Thomas, Us Virgin Islands. Am. J. Epidemiol. 2011, 173, S224.

165. Radke, E.G.; Grattan, L.M.; Cook, R.L.; Smith, T.B.; Anderson, D.M.; Morris, J.G. Ciguatera Incidence in the US Virgin Islands Has Not Increased over a 30-Year Time Period Despite Rising Seawater Temperatures. Am. J. Trop. Med. Hyg. 2013, 88, 908-913. [CrossRef] [PubMed]

166. Friedemann, M. Tropical fish poisonings in Germany 2012-2017-What is ciguatera? Int. J. Infect. Dis. 2019, 79, 130. [CrossRef]

167. Ting, J.Y.; Brown, A.F. Ciguatera poisoning: A global issue with common management problems. Eur. J. Emerg. Med. 2001, 8, 295-300. [CrossRef]

168. Schlaich, C.; Hagelstein, J.G.; Burchard, G.D.; Schmiedel, S. Outbreak of ciguatera fish poisoning on a cargo ship in the port of Hamburg. J. Travel Med. 2012, 19, 238-242. [CrossRef]

169. Au, N.P.B.; Kumar, G.; Asthana, P.; Tin, C.; Mak, Y.L.; Chan, L.L.; Lam, P.K.S.; Ma, C.H.E. Ciguatoxin reduces regenerative capacity of axotomized peripheral neurons and delays functional recovery in pre-exposed mice after peripheral nerve injury. Sci. Rep. 2016, 6, 26809. [CrossRef]

170. Wang, J.; Cao, B.; Yang, X.; Wu, J.; Chan, L.L.; Li, Y. Chronic ciguatoxin poisoning causes emotional and cognitive dysfunctions in rats. Toxicol. Res. 2016, 6, 179-187. [CrossRef] [PubMed]

171. Ryan, J.C.; Wu, Q.; Shoemaker, R.C. Transcriptomic signatures in whole blood of patients who acquire a chronic inflammatory response syndrome (CIRS) following an exposure to the marine toxin ciguatoxin. BMC Med. Genom. 2015, 8, 15. [CrossRef]

172. Bilbao-Sieyro, A.; Pérez-González, Y.; Pavón-Salas, N.; De La Cruz-Modino, R.; Chinea-Mederos, I.; Tabares-Santos, J.L.; CabreraSuárez, F. Acquired knowledge about ciguatera fish poisoning in the Canary Islands population. Front. Mar. Sci. 2019. [CrossRef]

173. Wang, Z.; Fuquay, J.M.; Ledreux, A.; Barbieri, M.; Ramsdell, J.S. Sample preparation and liquid chromatography-tandem mass spectrometry for the analysis of selected Pacific ciguatoxins in blood samples. J. Chromatogr. A 2020, 1621, 461050. [CrossRef] [PubMed]

174. Bottein Dechraoui, M.-Y.; Wang, Z.; Ramsdell, J.S. Optimization of ciguatoxin extraction method from blood for Pacific ciguatoxin (P-CTX-1). Toxicon 2007, 49, 100-105. [CrossRef] [PubMed]

175. Moller, B.; Voglhuber-Slavinsky, A.; Dönitz, E.; Rosa, A. 50 Trends Influencing Europe's Food Sector by 2035; Fraunhofer Institute for Systems and Innovations Research ISI: Karlsruhe, Germany, 2019.

176. Saari, U.A.; Herstatt, C.; Tiwari, R.; Dedehayir, O.; Mäkinen, S.J. The vegan trend and the microfoundations of institutional change: A commentary on food producers' sustainable innovation journeys in Europe. Trends Food Sci. Technol. 2020. [CrossRef]

177. Gvion, L. Generation V: Millennial Vegans in Israel. J. Contemp. Ethnogr. 2020, 49, 564-586. [CrossRef]

178. Hopwood, C.J.; Bleidorn, W.; Schwaba, T.; Chen, S. Health, environmental, and animal rights motives for vegetarian eating. PLoS ONE 2020, 15, e0230609. [CrossRef] [PubMed]

179. Radke, E.G.; Reich, A.; Morris, J.G. Epidemiology of Ciguatera in Florida. Am. J. Trop. Med. Hyg. 2015, 93, 425-432. [CrossRef] [PubMed]

180. EUMOFA. The EU Fish Market; European Market Observatory for Fisheries and Aquaculture Products; European Union: Luxembourg, 2019; p. 107. [CrossRef]

181. EFSA. Panel on Contaminants in the Food Chain; Scientific Opinion on marine biotoxins in shellfish-Emerging toxins: Ciguatoxin group. EFSA J. 2010, 8, 1627. [CrossRef]

182. Bienfang, P.; DeFelice, S.; Dowling, A. Quantitative evaluation of commercially available test kit for ciguatera in fish. Food Nutr. Sci. 2011, 2, 6617. [CrossRef]

183. Dickey, R.W.; Plakas, S.M. Ciguatera: A public health perspective. Toxicon 2010, 56, 123-136. [CrossRef]

184. Botana, L.M. Seafood and Freshwater Toxins: Pharmacology, Physiology, and Detection, 3rd ed.; Botana, L.M., Ed.; CRC Press: Boca Raton, FL, USA, 2014; pp. 33487-33742.

185. Murray, J.S.; Harwood, D.T.; Rhodes, L.L. Ciguatera fish poisoning event in New Zealand from imported tropical reef fish and confirmation of Pacific ciguatoxins by LC-MS/MS. Harmful Algae News 2020, 66, 4-5.

186. Abraham, A.; Jester, E.L.E.; Granade, H.R.; Plakas, S.M.; Dickey, R.W. Caribbean ciguatoxin profile in raw and cooked fish implicated in ciguatera. Food Chem. 2012, 131, 192-198. [CrossRef]

187. Cohen, N.J.; Deeds, J.R.; Wong, E.S.; Hanner, R.H.; Yancy, H.F.; White, K.D.; Thompson, T.M.; Wahl, M.; Pham, T.D.; Guichard, F.M.; et al. Public health response to puffer fish (Tetrodotoxin) poisoning from mislabeled product. J. Food Prot. 2009, 72, 810-817. [CrossRef] [PubMed]

188. Cole, J.B.; Heegaard, W.G.; Deeds, J.R.; McGrath, S.C.; Handy, S.M. Tetrodotoxin poisoning outbreak from imported dried puffer fish-Minneapolis, Minnesota, 2014. MMWR Morb. Mortal. Wkly. Rep. 2015, 63, 1222-1225. 
189. Willette, D.A.; Simmonds, S.E.; Cheng, S.H.; Esteves, S.; Kane, T.L.; Nuetzel, H.; Pilaud, N.; Rachmawati, R.; Barber, P.H. Using DNA barcoding to track seafood mislabeling in Los Angeles restaurants. Conserv. Biol. 2017, 31, 1076-1085. [CrossRef] [PubMed]

190. Deeds, J.R.; Handy, S.M.; Fry, J.F.; Granade, H.; Williams, J.T.; Powers, M.; Shipp, R.; Weigt, L.A. Protocol for building a reference standard sequence library for DNA-based seafood identification. J. AOAC Int. 2014, 97, 1626-1633. [CrossRef]

191. Eischeid, A.C.; Stadig, S.R.; Handy, S.M.; Fry, F.S.; Deeds, J. Optimization and evaluation of a method for the generation of DNA barcodes for the identification of crustaceans. LWT 2016, 73, 357-367. [CrossRef]

192. Wong, L.L.; Peatman, E.; Lu, J.; Kucuktas, H.; He, S.; Zhou, C.; Na-nakorn, U.; Liu, Z. DNA Barcoding of Catfish: Species Authentication and Phylogenetic Assessment. PLoS ONE 2011, 6, e17812. [CrossRef]

193. Handy, S.M.; Deeds, J.R.; Ivanova, N.V.; Hebert, P.D.N.; Hanner, R.H.; Ormos, A.; Weigt, L.A.; Moore, M.M.; Yancy, H.F. A singlelaboratory validated method for the generation of DNA barcodes for the identification of fish for regulatory compliance. J. AOAC Int. 2011, 94, 201-210. [CrossRef]

194. Schoelinck, C.; Hinsinger, D.D.; Dettaï, A.; Cruaud, C.; Justine, J.-L. A Phylogenetic Re-Analysis of Groupers with Applications for Ciguatera Fish Poisoning. PLoS ONE 2014, 9, e98198. [CrossRef] [PubMed]

195. Ha, D.V.; Uesugi, A.; Uchida, H.; Ky, P.X.; Minh, D.Q.; Watanabe, R.; Matsushima, R.; Oikawa, H.; Nagai, S.; Iwataki, M.; et al. Identification of Causative Ciguatoxins in Red Snappers Lutjanus bohar Implicated in Ciguatera Fish Poisonings in Vietnam. Toxins 2018, 10, 420. [CrossRef] [PubMed]

196. Magras, J.; Olsen, D. St. Thomas Fishermen's Association: Involving Fishermen in Fishery Management. Proc. Sixty Fifth Annu. Gulf Caribb. Fish. Inst. 2012, 65, 48-51.

197. Howson, P. Building trust and equity in marine conservation and fisheries supply chain management with blockchain. Mar. Policy 2020, 115, 103873. [CrossRef]

198. Brownscombe, J.W.; Griffin, L.P.; Morley, D.; Acosta, A.; Hunt, J.; Lowerre-Barbieri, S.K.; Adams, A.J.; Danylchuk, A.J.; Cooke, S.J. Application of machine learning algorithms to identify cryptic reproductive habitats using diverse information sources. Oecologia 2020, 194, 283-298. [CrossRef]

199. Probst, W.N. How emerging data technologies can increase trust and transparency in fisheries. ICES J. Mar. Sci. 2019, 77, 1286-1294. [CrossRef]

200. Cook, B. Blockchain: Transforming the seafood supply chain. In World Wide Fund for Nature; World Wide Fund for Nature, WWF: Gland, Switzerland, 2018.

201. Gopi, K.; Mazumder, D.; Sammut, J.; Saintilan, N. Determining the provenance and authenticity of seafood: A review of current methodologies. Trends Food Sci. Technol. 2019, 91, 294-304. [CrossRef]

202. Tsolakis, N.; Niedenzu, D.; Simonetto, M.; Dora, M.; Kumar, M. Supply network design to address United Nations Sustainable Development Goals: A case study of blockchain implementation in Thai fish industry. J. Bus. Res. 2020. [CrossRef]

203. Caillaud, A.; de la Iglesia, P.; Darius, H.T.; Pauillac, S.; Aligizaki, K.; Fraga, S.; Chinain, M.; Diogene, J. Update on methodologies available for ciguatoxin determination: Perspectives to confront the onset of ciguatera fish poisoning in Europe. Mar. Drugs 2010, 8, 1838-1907. [CrossRef] [PubMed]

204. Estevez, P.; Castro, D.; Manuel Leao, J.; Yasumoto, T.; Dickey, R.; Gago-Martinez, A. Implementation of liquid chromatography tandem mass spectrometry for the analysis of ciguatera fish poisoning in contaminated fish samples from Atlantic coasts. Food Chem. 2019, 280, 8-14. [CrossRef] [PubMed]

205. Murray, J.S.; Boundy, M.J.; Selwood, A.I.; Harwood, D.T. Development of an LC-MS/MS method to simultaneously monitor maitotoxins and selected ciguatoxins in algal cultures and P-CTX-1B in fish. Harmful Algae 2018, 80, 80-87. [CrossRef]

206. Harwood, D.T.; Murray, S.; Boundy, M.J. Sample preparation prior to marine toxin analysis. In Recent Advances in the Analysis of Marine Toxins; Elsevier: Amsterdam, The Netherlands, 2017; Volume 78.

207. Hardison, D.R.; Holland, W.C.; McCall, J.R.; Bourdelais, A.J.; Baden, D.G.; Darius, H.T.; Chinain, M.; Tester, P.A.; Shea, D.; Flores Quintana, H.A.; et al. Fluorescent Receptor Binding Assay for Detecting Ciguatoxins in Fish. PLoS ONE 2016, 11, e0153348. [CrossRef]

208. Pawlowiez, R.; Darius, H.T.; Cruchet, P.; Rossi, F.; Caillaud, A.; Laurent, D.; Chinain, M. Evaluation of seafood toxicity in the Australes archipelago (French Polynesia) using the neuroblastoma cell-based assay. Food Addit. Contam. Part A 2013, 30, 567-586. [CrossRef] [PubMed]

209. FAO. Marine Biotoxins FAO Food and Nutrition Paper 80; Food and Agriculture Organization of the United Nations: Rome, Italy, 2004.

210. Dickey, R.W. Ciguatera Toxins: Chemistry, Toxicology, and Detection, 2nd ed.; CRC Press/Taylor \& Franci: New York, NY, USA, 2008; Volume 173, p. 22.

211. Viallon, J.; Chinain, M.; Darius, H.T. Revisiting the Neuroblastoma Cell-Based Assay (CBA-N2a) for the Improved Detection of Marine Toxins Active on Voltage Gated Sodium Channels (VGSCs). Toxins 2020, 12, 281. [CrossRef] [PubMed]

212. Manger, R.L.; Leja, L.S.; Lee, S.Y.; Hungerford, J.M.; Hokama, Y.; Dickey, R.W.; Granade, H.R.; Lewis, R.; Yasumoto, T.; Wekell, M.M. Detection of sodium channel toxins: Directed cytotoxicity assays of purified ciguatoxins, brevetoxins, saxitoxins, and seafood extracts. J. AOAC Int. 1995, 78, 521-527. [CrossRef] [PubMed]

213. Caillaud, A.; Cañete, E.; de la Iglesia, P.; Giménez, G.; Diogène, J. Cell-based assay coupled with chromatographic fractioning: A strategy for marine toxins detection in natural samples. Toxicol. In Vitro 2009, 23, 1591-1596. [CrossRef] [PubMed]

214. Campora, C.E.; Dierking, J.; Tamaru, C.S.; Hokama, Y.; Vincent, D. Detection of ciguatoxin in fish tissue using sandwich ELISA and neuroblastoma cell bioassay. J. Clin. Lab. Anal. 2008, 22, 246-253. [CrossRef] 
215. Tsumuraya, T.; Sato, T.; Hirama, M.; Fujii, I. Highly Sensitive and Practical Fluorescent Sandwich ELISA for Ciguatoxins. Anal. Chem. 2018, 90, 7318-7324. [CrossRef] [PubMed]

216. Leonardo, S.; Gaiani, G.; Tsumuraya, T.; Hirama, M.; Turquet, J.; Sagristà, N.; Rambla-Alegre, M.; Flores, C.; Caixach, J.; Diogene, J.; et al. Addressing the analytical challenges for the detection of ciguatoxins using an electrochemical biosensor. Anal. Chem. 2020. [CrossRef] [PubMed]

217. Díaz-Asencio, L.; Clausing, R.J.; Rañada, M.L.; Alonso-Hernández, C.M.; Dechraoui Bottein, M.-Y. A radioligand receptor binding assay for ciguatoxin monitoring in environmental samples: Method development and determination of quality control criteria. J. Environ. Radioact. 2018, 192, 289-294. [CrossRef] [PubMed]

218. Dechraoui Bottein, M.-Y.; Clausing, R.J. Chapter Eight-Receptor-Binding Assay for the Analysis of Marine Toxins: Detection and Mode of Action. In Comprehensive Analytical Chemistry; Diogène, J., Campàs, M., Eds.; Elsevier: Amsterdam, The Netherlands, 2017; Volume 78, pp. 277-301.

219. Loeffler, C.R.; Bodi, D.; Tartaglione, L.; Dell'Aversano, C.; Preiss-Weigert, A. Improving in vitro ciguatoxin and brevetoxin detection: Selecting neuroblastoma (Neuro-2a) cells with lower sensitivity to ouabain and veratridine (OV-LS). Harmful Algae 2021, 103, 101994. [CrossRef]

220. Estevez, P.; Sibat, M.; Leão-Martins, J.M.; Reis Costa, P.; Gago-Martínez, A.; Hess, P. Liquid chromatography coupled to highresolution mass spectrometry for the confirmation of Caribbean ciguatoxin-1 as the main toxin responsible for ciguatera poisoning caused by fish from European Atlantic coasts. Toxins 2020, 12, 267. [CrossRef]

221. Lewis, R.J.; Jones, A.; Vernoux, J.-P. HPLC/Tandem Electrospray Mass Spectrometry for the Determination of Sub-ppb Levels of Pacific and Caribbean Ciguatoxins in Crude Extracts of Fish. Anal. Chem. 1999, 71, 247-250. [CrossRef] [PubMed]

222. Wong, C.-K.; Hung, P.; Lo, J.Y. Ciguatera fish poisoning in Hong Kong-A 10-year perspective on the class of ciguatoxins. Toxicon 2014, 86, 96-106. [CrossRef] [PubMed]

223. Lewis, R.J.; Yang, A.; Jones, A. Rapid extraction combined with LC-tandem mass spectrometry (CREM-LC/MS/MS) for the determination of ciguatoxins in ciguateric fish flesh. Toxicon 2009, 54, 62-66. [CrossRef]

224. Darius, H.T.; Drescher, O.; Ponton, D.; Pawlowiez, R.; Laurent, D.; Dewailly, E.; Chinain, M. Use of folk tests to detect ciguateric fish: A scientific evaluation of their effectiveness in Raivavae Island (Australes, French Polynesia). Food Addit. Contam. Part A 2012, 30, 550-566. [CrossRef] [PubMed]

225. Pasinszki, T.; Lako, J.; Dennis, T.E. Advances in Detecting Ciguatoxins in Fish. Toxins 2020, 12, 494. [CrossRef] [PubMed]

226. Bodero, M.; Gerssen, A.; Portier, L.; Klijnstra, M.; Hoogenboom, R.; Guzmán, L.; Hendriksen, P.; Bovee, T. A Strategy to Replace the Mouse Bioassay for Detecting and Identifying Lipophilic Marine Biotoxins by Combining the Neuro-2a Bioassay and LC-MS/MS Analysis. Mar. Drugs 2018, 16, 501. [CrossRef] [PubMed]

227. L'Herondelle, K.; Talagas, M.; Mignen, O.; Misery, L.; Le Garrec, R. Neurological Disturbances of Ciguatera Poisoning: Clinical Features and Pathophysiological Basis. Cells 2020, 9, 2291. [CrossRef]

228. Freshney, R.I. Serum-Free Media. In Culture of Animal Cells; Freshney, R.I., Ed.; John Wiley \& Sons, Inc.: New Jersey, NJ, USA, 2005; pp. 129-143. [CrossRef]

229. Andrée, B.; Ichanti, H.; Kalies, S.; Heisterkamp, A.; Strauß, S.; Vogt, P.-M.; Haverich, A.; Hilfiker, A. Formation of threedimensional tubular endothelial cell networks under defined serum-free cell culture conditions in human collagen hydrogels. Sci. Rep. 2019, 9, 1-11. [CrossRef] [PubMed]

230. Brunner, D.; Frank, J.; Appl, H.; Schöffl, H.; Pfaller, W.; Gstraunthaler, G. The serum-free media interactive online database. ALTEX-Altern. Anim. Exp. 2010, 27, 53-62.

231. Bodero, M.; Bovee, T.F.H.; Wang, S.; Hoogenboom, R.L.A.P.; Klijnstra, M.D.; Portier, L.; Hendriksen, P.J.M.; Gerssen, A. Screening for the presence of lipophilic marine biotoxins in shellfish samples using the neuro-2a bioassay. Food Addit. Contam. Part A 2018, 35, 351-365. [CrossRef]

232. Gstraunthaler, G. Alternatives to the use of fetal bovine serum: Serum-free cell culture. ALTEX-Altern. Anim. Exp. 2003, 20, 275-281.

233. Cong, L.; Ran, F.A.; Cox, D.; Lin, S.; Barretto, R.; Habib, N.; Hsu, P.D.; Wu, X.; Jiang, W.; Marraffini, L.A. Multiplex genome engineering using CRISPR/Cas systems. Science 2013, 339, 819-823. [CrossRef]

234. Mali, P.; Yang, L.; Esvelt, K.M.; Aach, J.; Guell, M.; DiCarlo, J.E.; Norville, J.E.; Church, G.M. RNA-guided human genome engineering via Cas9. Science 2013, 339, 823-826. [CrossRef]

235. Ran, F.A.; Hsu, P.D.; Wright, J.; Agarwala, V.; Scott, D.A.; Zhang, F. Genome engineering using the CRISPR-Cas9 system. Nat. Protoc. 2013, 8, 2281-2308. [CrossRef] [PubMed]

236. Van Der Oost, J.; Westra, E.R.; Jackson, R.N.; Wiedenheft, B. Unravelling the structural and mechanistic basis of CRISPR-Cas systems. Nat. Rev. Microbiol. 2014, 12, 479-492. [CrossRef] [PubMed]

237. Shalem, O.; Sanjana, N.E.; Hartenian, E.; Shi, X.; Scott, D.A.; Mikkelsen, T.S.; Heckl, D.; Ebert, B.L.; Root, D.E.; Doench, J.G. Genome-scale CRISPR-Cas9 knockout screening in human cells. Science 2014, 343, 84-87. [CrossRef] [PubMed]

238. Bratovič, M.; Fonfara, I.; Chylinski, K.; Gálvez, E.J.C.; Sullivan, T.J.; Boerno, S.; Timmermann, B.; Boettcher, M.; Charpentier, E. Bridge helix arginines play a critical role in Cas9 sensitivity to mismatches. Nat. Chem. Biol. 2020, 16, 587-595. [CrossRef] [PubMed]

239. Hsu, P.D.; Lander, E.S.; Zhang, F. Development and applications of CRISPR-Cas9 for genome engineering. Cell 2014, 157, 1262-1278. [CrossRef] [PubMed] 
240. Dib-Hajj, S.D.; Rush, A.M.; Cummins, T.R.; Hisama, F.M.; Novella, S.; Tyrrell, L.; Marshall, L.; Waxman, S.G. Gain-of-function mutation in Nav1.7 in familial erythromelalgia induces bursting of sensory neurons. Brain 2005, 128, 1847-1854. [CrossRef]

241. Han, C.; Yang, Y.; de Greef, B.T.; Hoeijmakers, J.G.; Gerrits, M.M.; Verhamme, C.; Qu, J.; Lauria, G.; Merkies, I.S.; Faber, C.G.; et al. The Domain II S4-S5 Linker in Nav1.9: A Missense Mutation Enhances Activation, Impairs Fast Inactivation, and Produces Human Painful Neuropathy. Neuromol. Med. 2015, 17, 158-169. [CrossRef]

242. Leipold, E.; Liebmann, L.; Korenke, G.C.; Heinrich, T.; Giesselmann, S.; Baets, J.; Ebbinghaus, M.; Goral, R.O.; Stödberg, T.; Hennings, J.C.; et al. A de novo gain-of-function mutation in SCN11A causes loss of pain perception. Nat. Genet. 2013, 45, 1399-1404. [CrossRef]

243. Leipold, E.; Hanson-Kahn, A.; Frick, M.; Gong, P.; Bernstein, J.A.; Voigt, M.; Katona, I.; Oliver Goral, R.; Altmüller, J.; Nürnberg, P.; et al. Cold-aggravated pain in humans caused by a hyperactive NaV1.9 channel mutant. Nat. Commun. 2015, 6, 10049. [CrossRef] [PubMed]

244. Faber, C.G.; Lauria, G.; Merkies, I.S.; Cheng, X.; Han, C.; Ahn, H.S.; Persson, A.K.; Hoeijmakers, J.G.; Gerrits, M.M.; Pierro, T.; et al. Gain-of-function Nav1.8 mutations in painful neuropathy. Proc. Natl. Acad. Sci. USA 2012, 109, 19444-19449. [CrossRef] [PubMed]

245. Sun, L.; Lutz, B.M.; Tao, Y.-X. The CRISPR/Cas9 system for gene editing and its potential application in pain research. Transl. Perioper. Pain Med. 2016, 1, 22-33. [PubMed]

246. Al-Sabi, A.; McArthur, J.; Ostroumov, V.; French, R.J. Marine Toxins That Target Voltage-gated Sodium Channels. Mar. Drugs 2006, 4, 157-192. [CrossRef]

247. Bergholz, T.M.; Moreno Switt, A.I.; Wiedmann, M. Omics approaches in food safety: Fulfilling the promise? Trends Microbiol. 2014, 22, 275-281. [CrossRef]

248. Campos, A.; Freitas, M.; de Almeida, A.M.; Martins, J.C.; Domínguez-Pérez, D.; Osório, H.; Vasconcelos, V.; Reis Costa, P. OMICs Approaches in Diarrhetic Shellfish Toxins Research. Toxins 2020, 12, 493. [CrossRef] [PubMed]

249. Yao, Z.; Petschnigg, J.; Ketteler, R.; Stagljar, I. Application guide for omics approaches to cell signaling. Nat. Chem. Biol. 2015, 11, 387. [CrossRef] [PubMed]

250. Sapcariu, S.C.; Kanashova, T.; Weindl, D.; Ghelfi, J.; Dittmar, G.; Hiller, K. Simultaneous extraction of proteins and metabolites from cells in culture. MethodsX 2014, 1, 74-80. [CrossRef]

251. Matsumoto, M.; Hiyama, T.Y.; Kuboyama, K.; Suzuki, R.; Fujikawa, A.; Noda, M. Channel Properties of Nax Expressed in Neurons. PLoS ONE 2015, 10, e0126109. [CrossRef] [PubMed]

252. Tsumuraya, T.; Fujii, I.; Hirama, M. Production of monoclonal antibodies for sandwich immunoassay detection of Pacific ciguatoxins. Toxicon 2010, 56, 797-803. [CrossRef] [PubMed]

253. Tsumuraya, T.; Fujii, I.; Inoue, M.; Tatami, A.; Miyazaki, K.; Hirama, M. Production of monoclonal antibodies for sandwich immunoassay detection of ciguatoxin 51-hydroxyCTX3C. Toxicon 2006, 48, 287-294. [CrossRef]

254. Tsumuraya, T.; Fujii, I.; Hirama, M. Preparation of anti-ciguatoxin monoclonal antibodies using synthetic haptens: Sandwich ELISA detection of ciguatoxins. J. AOAC Int. 2014, 97, 373-379. [CrossRef] [PubMed]

255. Tsumuraya, T.; Hirama, M. Rationally Designed Synthetic Haptens to Generate Anti-Ciguatoxin Monoclonal Antibodies, and Development of a Practical Sandwich ELISA to Detect Ciguatoxins. Toxins 2019, 11, 533. [CrossRef] [PubMed]

256. Tsumuraya, T.; Takeuchi, K.; Yamashita, S.; Fujii, I.; Hirama, M. Development of a monoclonal antibody against the left wing of ciguatoxin CTX1B: Thiol strategy and detection using a sandwich ELISA. Toxicon 2012, 60, 348-357. [CrossRef] [PubMed]

257. Campora, C.E.; Hokama, Y.; Yabusaki, K.; Isobe, M. Development of an enzyme-linked immunosorbent assay for the detection of ciguatoxin in fish tissue using chicken immunoglobulin Y. J. Clin. Lab. Anal. 2008, 22, 239-245. [CrossRef] [PubMed]

258. Gaiani, G.; Leonardo, S.; Tudó, À.; Toldrà, A.; Rey, M.; Andree, K.B.; Tsumuraya, T.; Hirama, M.; Diogène, J.; O'Sullivan, C.K.; et al. Rapid detection of ciguatoxins in Gambierdiscus and Fukuyoa with immunosensing tools. Ecotoxicol. Environ. Saf. 2020, 204, 111004. [CrossRef]

259. Zhang, Z.; Zhang, C.; Luan, W.; Li, X.; Liu, Y.; Luo, X. Ultrasensitive and accelerated detection of ciguatoxin by capillary electrophoresis via on-line sandwich immunoassay with rotating magnetic field and nanoparticles signal enhancement. Anal. Chim. Acta 2015, 888, 27-35. [CrossRef] [PubMed]

260. Li, T.; Li, H.; Gao, S.; Hua, X.; Yang, C.; Chen, C.; Yan, F.; Zhu, S.; Li, T. Metalens-integrated compact imaging devices for wide-field microscopy. Adv. Photon. 2020, 2, 66004.

261. Parolo, C.; Sena-Torralba, A.; Bergua, J.F.; Calucho, E.; Fuentes-Chust, C.; Hu, L.; Rivas, L.; Álvarez-Diduk, R.; Nguyen, E.P.; Cinti, S.; et al. Tutorial: Design and fabrication of nanoparticle-based lateral-flow immunoassays. Nat. Protoc. 2020. [CrossRef] [PubMed]

262. Sigal, Y.M.; Zhou, R.; Zhuang, X. Visualizing and discovering cellular structures with super-resolution microscopy. Science 2018, 361, 880-887. [CrossRef] [PubMed]

263. Huang, F.; Sirinakis, G.; Allgeyer, E.S.; Schroeder, L.K.; Duim, W.C.; Kromann, E.B.; Phan, T.; Rivera-Molina, F.E.; Myers, J.R.; Irnov, I.; et al. Ultra-High Resolution 3D Imaging of Whole Cells. Cell 2016, 166, 1028-1040. [CrossRef]

264. Kang, J.W.; So, P.T.C.; Dasari, R.R.; Lim, D.-K. High Resolution Live Cell Raman Imaging Using Subcellular Organelle-Targeting SERS-Sensitive Gold Nanoparticles with Highly Narrow Intra-Nanogap. Nano Lett. 2015, 15, 1766-1772. [CrossRef] [PubMed]

265. Smith, R.; Wright, K.L.; Ashton, L. Raman spectroscopy: An evolving technique for live cell studies. Analyst 2016, 141, 3590-3600. [CrossRef]

266. Jager, J.; Gerssen, A.; Pawliszyn, J.; Sterk, S.S.; Nielen, M.W.F.; Blokland, M.H. USB-Powered Coated Blade Spray Ion Source for On-Site Testing Using Transportable Mass Spectrometry. J. Am. Soc. Mass Spectrom. 2020, 31, 2243-2249. [CrossRef] 
267. Mielczarek, P.; Silberring, J.; Smoluch, M. Minaturization in mass spectrometry. Mass Spectrom. Rev. 2020, 39, 453-470. [CrossRef]

268. Blokland, M.H.; Gerssen, A.; Zoontjes, P.W.; Pawliszyn, J.; Nielen, M.W.F. Potential of recent ambient ionization techniques for future food contaminant analysis using (trans)portable mass spectrometry. Food Anal. Methods 2020, 13, 706-717. [CrossRef]

269. Inoue, M.; Hirama, M. Total synthesis of ciguatoxin CTX3C, a causative toxin of ciguatera seafood poisoning. Synlett 2004. [CrossRef]

270. Hirama, M.; Oishi, T.; Uehara, H.; Inoue, M.; Maruyama, M.; Oguri, H.; Satake, M. Total synthesis of ciguatoxin CTX3C. Science 2001, 294, 1904-1907. [CrossRef] [PubMed]

271. EFSA. Panel on Contaminants in the Food Chain; Scientific Opinion on marine biotoxins in shellfish-Emerging toxins: Brevetoxin group. EFSA J. 2010, 8. [CrossRef]

272. Hastings, R.A.; Rutterford, L.A.; Freer, J.J.; Collins, R.A.; Simpson, S.D.; Genner, M.J. Climate change drives poleward increases and equatorward declines in marine species. Curr. Biol. 2020, 30, 1572-1577. [CrossRef] [PubMed]

273. Nicholls, R.J.; Cazenave, A. Sea-Level Rise and Its Impact on Coastal Zones. Science 2010, 328, 1517-1520. [CrossRef] [PubMed]

274. Church, J.A.; White, N.J. Sea-Level Rise from the Late 19th to the Early 21st Century. Surv. Geophys. 2011, 32, 585-602. [CrossRef]

275. Hales, S.; Weinstein, P.; Woodward, A. Ciguatera (Fish Poisoning), El Niño, and Pacific Sea Surface Temperatures. Ecosyst. Health 1999, 5, 20-25. [CrossRef]

276. Rhodes, L.L.; Smith, K.F.; Murray, J.S.; Nishimura, T.; Finch, S.C. Ciguatera Fish Poisoning: The Risk from an Aotearoa/New Zealand Perspective. Toxins 2020, 12, 50. [CrossRef]

277. Bove, G.; Becker, A.; Sweeney, B.; Vousdoukas, M.; Kulp, S. A method for regional estimation of climate change exposure of coastal infrastructure: Case of USVI and the influence of digital elevation models on assessments. Sci. Total Environ. 2020, 710, 136162. [CrossRef] [PubMed]

278. Heron, S.; van Hooidonk, R.; Maynard, J.; Anderson, K.; Day, J.; Geiger, E.; Hoegh-Guldberg, O.; Hughes, T.; Marshall, P.; Obura, D. Impacts of Climate Change on World Heritage coral Reefs: Update to the First Global Scientific Assessment; UNESCO World Heritage Centre: Paris, France, 2018.

279. Dietzel, A.; Bode, M.; Connolly, S.R.; Hughes, T.P. Long-term shifts in the colony size structure of coral populations along the Great Barrier Reef. Proc. R. Soc. B Biol. Sci. 2020, 287, 20201432. [CrossRef] [PubMed]

280. Yates, K.K.; Zawada, D.G.; Smiley, N.A.; Tiling-Range, G. Divergence of seafloor elevation and sea level rise in coral reef ecosystems. Biogeosciences 2017, 14, 1739. [CrossRef]

281. Ciro Aucelli, P.P.; Di Paola, G.; Incontri, P.; Rizzo, A.; Vilardo, G.; Benassai, G.; Buonocore, B.; Pappone, G. Coastal inundation risk assessment due to subsidence and sea level rise in a Mediterranean alluvial plain (Volturno coastal plain—southern Italy). Estuar Coast. Shelf Sci. 2017, 198, 597-609. [CrossRef]

282. Beck, M.W.; Losada, I.J.; Menéndez, P.; Reguero, B.G.; Díaz-Simal, P.; Fernández, F. The global flood protection savings provided by coral reefs. Nat. Commun. 2018, 9, 1-9. [CrossRef]

283. Leatherman, S.P.; Beller-Simms, N. Sea-level rise and small island states: An overview. J. Coast. Res. 1997, 1-16.

284. Hughes, T.P. Catastrophes, phase shifts, and large-scale degradation of a Caribbean coral reef. Science 1994, 265, 1547-1551. [CrossRef]

285. McManus, J.W.; Meñez, L.A.B.; Kesner-Reyes, K.N.; Vergara, S.G.; Ablan, M.C. Coral reef fishing and coral-algal phase shifts: Implications for global reef status. ICES J. Mar. Sci. 2000, 57, 572-578. [CrossRef]

286. McManus, J.W.; Polsenberg, J.F. Coral-algal phase shifts on coral reefs: Ecological and environmental aspects. Prog. Oceanogr. 2004, 60, 263-279. [CrossRef]

287. Kohler, S.; Kohler, C. Dead bleached coral provides new surfaces for dinoflagellates implicated in ciguatera fish poisonings. Environ. Biol. Fish 1992, 35, 413-416. [CrossRef]

288. Nakahara, H.; Sakami, T.; Chinain, M.; Ishida, Y. The role of macroalgae in epiphytism of the toxic dinoflagellate Gambierdiscus toxicus (Dinophyceae). Phycol. Res. 1996, 44, 113-117. [CrossRef]

289. Parsons, M.L.; Settlemier, C.J.; Ballauer, J.M. An examination of the epiphytic nature of Gambierdiscus toxicus, a dinoflagellate involved in ciguatera fish poisoning. Harmful Algae 2011, 10, 598-605. [CrossRef] [PubMed]

290. Skinner, M.P.; Lewis, R.J.; Morton, S. Ecology of the ciguatera causing dinoflagellates from the Northern Great Barrier Reef: Changes in community distribution and coastal eutrophication. Mar. Pollut. Bull. 2013, 77, 210-219. [CrossRef] [PubMed]

291. Cruz-Rivera, E.; Villareal, T.A. Macroalgal palatability and the flux of ciguatera toxins through marine food webs. Harmful Algae 2006, 5, 497-525. [CrossRef]

292. Chapman, D.; Ranelletti, M.; Kaushik, S. Invasive marine algae: An ecological perspective. Bot. Rev. 2006, 72, 153-178. [CrossRef]

293. Tester, P.; Wickliffe, L.; Jossart, J.; Rhodes, L.; Enevoldsen, H.; Adachi, M.; Nishimura, T.; Rodriguez, F.; Chinain, M.; Litaker, W. Global distribution of the genera Gambierdiscus and Fukuyoa. Harmful Algae 2018-From Ecosystems to Socio-Ecosystems. In Proceedings of the 18th Internationalconference on Harmful Algae, Nantes, France, 21-26 October 2018; p. 138.

294. Masó, M.; Garcés, E.; Pagès, F.; Camp, J. Drifting plastic debris as a potential vector for dispersing Harmful Algal Bloom (HAB) species. Sci. Mar. 2003, 67, 107-111. [CrossRef]

295. Larsson, M.E.; Laczka, O.F.; Suthers, I.M.; Ajani, P.A.; Doblin, M.A. Hitchhiking in the east Australian current: Rafting as a dispersal mechanism for harmful epibenthic dinoflagellates. Mar. Ecol. Prog. Ser. 2018, 596, 49-60. [CrossRef]

296. Hallegraeff, G.M. Transport of harmful marine microalgae via ship's ballast water: Management and mitigation with special reference to the Arabian Gulf region. Aquat. Ecosyst. Health Manag. 2015, 18, 290-298. [CrossRef] 
297. Lewis, R.J. The changing face of ciguatera. Toxicon 2001,39, 97-106. [CrossRef]

298. Lewis, R.J. Ciguatera management. SPC Live Reef Fish Inf. Bull. 2000, 7, 11-13.

299. Murata, M.; Legrand, A.M.; Ishibashi, Y.; Fukui, M.; Yasumoto, T. Structures and configurations of ciguatoxin from the moray eel Gymnothorax javanicus and its likely precursor from the dinoflagellate Gambierdiscus toxicus. J. Am. Chem. Soc. 1990, 112, 4380-4386. [CrossRef]

300. Lewis, R.J.; Vernoux, J.-P.; Brereton, I.M. Structure of Caribbean Ciguatoxin Isolated from Caranx latus. J. Am. Chem. Soc. 1998, 120, 5914-5920. [CrossRef]

301. Núñez-Vázquez, E.J.; Almazán-Becerril, A.; López-Cortés, D.J.; Heredia-Tapia, A.; Hernández-Sandoval, F.E.; Band-Schmidt, C.J.; Bustillos-Guzmán, J.J.; Gárate-Lizárraga, I.; García-Mendoza, E.; Salinas-Zavala, C.A.; et al. Ciguatera in Mexico (1984-2013). Mar. Drugs 2019, 17, 13. [CrossRef]

302. Navarro Quiroz, R.; Herrera-Usuga, J.C.; Osorio-Ospina, L.M.; Garcia-Pertuz, K.M.; Navarro Quiroz, E. Epidemiology and Toxicology of Ciguatera Poisoning in the Colombian Caribbean. Mar. Drugs 2020, 18, 504. [CrossRef]

303. Miller, D.M. Dinoflagellate Toxins Responsible for Ciguatera Food Poisoning. Southern Illinois University at Carbondale Department of Physiology: Carbondale, IL, USA, 1991.

304. Bomber, J.W.; Tindall, D.R.; Miller, D.M. Genetic variability in toxin protencies among seventeen clones of Gambierdiscus toxicus (Dinophyceae). J. Phycol. 1989, 25, 617-625. [CrossRef]

305. Tu, C.-Y.; Chen, K.-T.; Hsieh, C.-h. Fishing and temperature effects on the size structure of exploited fish stocks. Sci. Rep. 2018, 8 , 7132. [CrossRef]

306. Vermeij, M.J.; Latijnhouwers, K.R.; Dilrosun, F.; Chamberland, V.F.; Dubé, C.E.; Van Buurt, G.; Debrot, A.O. Historical changes (1905-present) in catch size and composition reflect altering fisheries practices on a small Caribbean island. PLoS ONE 2019, 14, e0217589. [CrossRef]

307. Audzijonyte, A.; Kuparinen, A.; Gorton, R.; Fulton, E.A. Ecological consequences of body size decline in harvested fish species: Positive feedback loops in trophic interactions amplify human impact. Biol. Lett. 2013, 9, 20121103. [CrossRef]

308. Dierking, J. Effects of the Introduced Predatory Fish Cephalopholis Argus on Native Reef Fish Populations in Hawaii. University of Hawaii at Manoa, Dept. of Zoology: Manoa, HI, USA, 2007.

309. Trehern, R.H.; Raguse, C.; Bigelow, W.F.; Garg, A.; Hauptman, H.; Brooks, A.; Van Leeuwen, T.E.; Hawkes, L.A. The effect of salinity on behavioural interactions between native Schoolmaster snapper (Lutjanus apodus) and invasive lionfish (Pterois spp.). J. Exp. Mar. Biol. Ecol. 2020, 530-531, 151414. [CrossRef]

310. Dierking, J.; Williams, I.D.; Walsh, W.J. Diet composition and prey selection of the introduced grouper species peacock hind (Cephalopholis argus) in Hawaii. Fish. Bull. 2009, 107, 464-476.

311. Birrell, C.L.; McCook, L.J.; Willis, B.L. Effects of algal turfs and sediment on coral settlement. Mar. Pollut. Bull. 2005, 51, 408-414. [CrossRef] [PubMed]

312. Hardison, D.R.; Holland, W.C.; Darius, H.T.; Chinain, M.; Tester, P.A.; Shea, D.; Bogdanoff, A.K.; Morris, J.A., Jr.; Flores Quintana, H.A.; Loeffler, C.R.; et al. Investigation of ciguatoxins in invasive lionfish from the greater Caribbean region: Implications for fishery development. PLoS ONE 2018, 13, e0198358. [CrossRef] [PubMed]

313. Soliño, L.; Widgy, S.; Pautonnier, A.; Turquet, J.; Loeffler, C.R.; Quintana, H.A.F.; Diogène, J. Prevalence of ciguatoxins in lionfish (Pterois spp.) from Guadeloupe, Saint Martin, and Saint Barthélmy Islands (Caribbean). Toxicon 2015, 102, 62-68. [CrossRef] [PubMed]

314. Robertson, A.; Garcia, A.C.; Quintana, H.A.F.; Smith, T.B.; Castillo, B.F., II; Reale-Munroe, K.; Gulli, J.A.; Olsen, D.A.; Hooe-Rollman, J.I.; Jester, E.L. Invasive lionfish (Pterois volitans): A potential human health threat for ciguatera fish poisoning in tropical waters. Mar. Drugs 2013, 12, 88-97. [CrossRef] [PubMed]

315. Dierking, J.; Campora, C.E. Ciguatera in the introduced fish Cephalopholis argus (Serranidae) in Hawai'i and implications for fishery management. Pac. Sci. 2009, 63, 193-204. [CrossRef]

316. Lester, S.E.; Halpern, B.S.; Grorud-Colvert, K.; Lubchenco, J.; Ruttenberg, B.I.; Gaines, S.D.; Airamé, S.; Warner, R.R. Biological effects within no-take marine reserves: A global synthesis. Mar. Ecol. Prog. Ser. 2009, 384, 33-46. [CrossRef]

317. Hyrenbach, K.D.; Forney, K.A.; Dayton, P.K. Marine protected areas and ocean basin management. Aquat. Conserv. Mar. Freshw. Ecosyst. 2000, 10, 437-458. [CrossRef]

318. Cinner, J.E.; Zamborain-Mason, J.; Gurney, G.G.; Graham, N.A.J.; MacNeil, M.A.; Hoey, A.S.; Mora, C.; Villéger, S.; Maire, E.; McClanahan, T.R.; et al. Meeting fisheries, ecosystem function, and biodiversity goals in a human-dominated world. Science 2020, 368, 307. [CrossRef] [PubMed]

319. Cabral, R.B.; Bradley, D.; Mayorga, J.; Goodell, W.; Friedlander, A.M.; Sala, E.; Costello, C.; Gaines, S.D. A global network of marine protected areas for food. Proc. Natl. Acad. Sci. USA 2020. [CrossRef] [PubMed]

320. Goñi, R.; Adlerstein, S.; Alvarez-Berastegui, D.; Forcada, A.; Reñones, O.; Criquet, G.; Polti, S.; Cadiou, G.; Valle, C.; Lenfant, P.; et al. Spillover from six western Mediterranean marine protected areas: Evidence from artisanal fisheries. Mar. Ecol. Prog. Ser. 2008, 366, 159-174. [CrossRef]

321. UNFCCC. Adoption of the Paris Agreement. Available online: http://unfccc.int/resource/docs/2015/cop21/eng/109r01.pdf (accessed on 15 October 2020).

322. Villareal, T.A.; Hanson, S.; Qualia, S.; Jester, E.L.E.; Granade, H.R.; Dickey, R.W. Petroleum production platforms as sites for the expansion of ciguatera in the northwestern Gulf of Mexico. Harmful Algae 2007, 6, 253-259. [CrossRef] 
323. Reubens, J.T.; Braeckman, U.; Vanaverbeke, J.; Van Colen, C.; Degraer, S.; Vincx, M. Aggregation at windmill artificial reefs: CPUE of Atlantic cod (Gadus morhua) and pouting (Trisopterus luscus) at different habitats in the Belgian part of the North Sea. Fish. Res. 2013, 139, 28-34. [CrossRef]

324. Glarou, M.; Zrust, M.; Svendsen, J.C. Using artificial-reef knowledge to enhance the ecological function of offshore wind turbine foundations: Implications for fish abundance and diversity. J. Mar. Sci. Eng. 2020, 8, 332. [CrossRef]

325. Siegel, F.R. Structures That Protect Coastal Populations, Assets, and GDPs: Sea Dikes, Breakwaters, Seawalls. In Adaptations of Coastal Cities to Global Warming, Sea Level Rise, Climate Change and Endemic Hazards; Siegel, F.R., Ed.; Springer: Cham, Switzerland, 2020; pp. 11-25. [CrossRef]

326. Raza, N. Physical Model Study of Living Breakwaters: Stability and Ecological Analysis of Green-Grey Hybrid Structure Concept for Climate Change Adaptation. Master's Thesis, Delft University of Technology, Delft, The Netherlands, 2019.

327. Danladi, I.B.; Kore, B.M.; Gül, M. Vulnerability of the Nigerian coast: An insight into sea level rise owing to climate change and anthropogenic activities. J. Afr. Earth Sci. 2017, 134, 493-503. [CrossRef]

328. FAO. Kyoto Conference Outcome and Papers Presented. Available online: http://www.fao.org/3/AC442e/AC442e00.htm (accessed on 6 November 2020).

329. UNEP. Nagoya Protocol on Access to Genetic Resources and the Fair and Equitable Sharing of Benefi ts Arising from their Utilization to the Convention on Biological Diversity; United Nations Environmental Programme; Secretariat of the Convention on Biological Diversity: Montreal, QC, Canada, 2010; ISBN 92-9225-306-9.

330. McCluskey, K.; Barker, K.B.; Barton, H.A.; Boundy-Mills, K.; Brown, D.R.; Coddington, J.A.; Cook, K.; Desmeth, P.; Geiser, D.; Glaeser, J.A.; et al. The U.S. Culture Collection Network Responding to the Requirements of the Nagoya Protocol on Access and Benefit Sharing. mBio 2017, 8, e00982-17. [CrossRef] [PubMed]

331. Filous, A.; Lennox, R.J.; Beaury, J.P.; Bagnis, H.; McHugh, M.; Friedlander, A.M.; Clua, E.E.G.; Cooke, S.J.; Fuller, T.K.; Danylchuk, A.J. Fisheries science and marine education catalyze the renaissance of traditional management (rahui) to improve an artisanal fishery in French Polynesia. Mar. Policy 2021, 123, 104291. [CrossRef]

332. O'Toole, A.C.; Danylchuk, A.J.; Suski, C.D.; Cooke, S.J. Consequences of catch-and-release angling on the physiological status, injury, and immediate mortality of great barracuda (Sphyraena barracuda) in The Bahamas. ICES J. Mar. Sci. J. Cons. 2010, 67, 1667-1675. [CrossRef]

333. O’Toole, A.C.; Dechraoui Bottein, M.-Y.; Danylchuk, A.J.; Ramsdell, J.S.; Cooke, S.J. Linking ciguatera poisoning to spatial ecology of fish: A novel approach to examining the distribution of biotoxin levels in the great barracuda by combining non-lethal blood sampling and biotelemetry. Sci. Total Environ. 2012, 427-428, 98-105. [CrossRef]

334. Marsh, H.; Eros, C.M. Ethics of field research: Do journals set the standard? Sci. Eng. Ethics 1999, 5, 375-382. [CrossRef]

335. Mangialajo, L.; Fricke, A.; Perez-Gutierrez, G.; Catania, D.; Jauzein, C.; Lemee, R. Benthic Dinoflagellate Integrator (BEDI): A new method for the quantification of Benthic Harmful Algal Blooms. Harmful Algae 2017, 64, 1-10. [CrossRef]

336. Xu, Y.; Richlen, M.L.; Morton, S.L.; Mak, Y.L.; Chan, L.L.; Tekiau, A.; Anderson, D.M. Distribution, abundance and diversity of Gambierdiscus spp. from a ciguatera-endemic area in Marakei, Republic of Kiribati. Harmful Algae 2014, 34, 56-68. [CrossRef]

337. Anderson, C.R.; Berdalet, E.; Kudela, R.M.; Cusack, C.K.; Silke, J.; O’Rourke, E.; Dugan, D.; McCammon, M.; Newton, J.A.; Moore, S.K.; et al. Scaling up from regional case studies to a global harmful algal bloom observing system. Front. Mar. Sci. 2019, 6, 250. [CrossRef]

338. Stauffer, B.A.; Bowers, H.A.; Buckley, E.; Davis, T.W.; Johengen, T.H.; Kudela, R.; McManus, M.A.; Purcell, H.; Smith, G.J.; Vander Woude, A.; et al. Considerations in Harmful Algal Bloom Research and Monitoring: Perspectives From a ConsensusBuilding Workshop and Technology Testing. Front. Mar. Sci. 2019, 6, 399. [CrossRef]

339. Berdalet, E.; Bravo, I.; Evans, J.; Fraga, S.; Kibler, S.; Kudela, M.; Larsen, J.; Litaker, W.; Penna, A.; Tester, P.; et al. Global Ecology and Oceanography of Harmful Algal Blooms, GEOHAB Core Research Project: HABs in Benthic Systems; Intergovernmental Oceanographic Commission. Scientific Committee on Oceanic Research (SCOR); Springer Nature: New York, NY, USA, 2012.

340. Brunson, J.K.; McKinnie, S.M.K.; Chekan, J.R.; McCrow, J.P.; Miles, Z.D.; Bertrand, E.M.; Bielinski, V.A.; Luhavaya, H.; Obornik, M.; Smith, G.J. Biosynthesis of the neurotoxin domoic acid in a bloom-forming diatom. Science 2018, 361. [CrossRef]

341. Hirama, M. Total synthesis of ciguatoxin CTX3C: A venture into the problems of ciguatera seafood poisoning. Chem. Rec. 2005, 5, 240-250. [CrossRef] [PubMed]

342. Inoue, M.; Miyazaki, K.; Uehara, H.; Maruyama, M.; Hirama, M. First- and second-generation total synthesis of ciguatoxin CTX3C. Proc. Natl. Acad. Sci. USA 2004, 101, 12013-12018. [CrossRef] [PubMed]

343. Inoue, M.; Miyazaki, K.; Ishihara, Y.; Tatami, A.; Ohnuma, Y.; Kawada, Y.; Komano, K.; Yamashita, S.; Lee, N.; Hirama, M. Total Synthesis of Ciguatoxin and 51-HydroxyCTX3C. J. Am. Chem. Soc. 2006, 128, 9352-9354. [CrossRef]

344. Hamajima, A.; Isobe, M. Total Synthesis of Ciguatoxin. Angew. Chem. Int. Ed. 2009, 48, 2941-2945. [CrossRef]

345. Furuta, H.; Hasegawa, Y.; Mori, Y. Total Synthesis of Gambierol. Org. Lett. 2009, 11, 4382-4385. [CrossRef] [PubMed]

346. Fuwa, H.; Noji, S.; Sasaki, M. Studies toward the Total Synthesis of Gambieric Acids: Stereocontrolled Synthesis of a DEFG-Ring Model Compound. J. Org. Chem. 2010, 75, 5072-5082. [CrossRef] [PubMed]

347. Fuwa, H.; Ishigai, K.; Hashizume, K.; Sasaki, M. Total Synthesis and Complete Stereostructure of Gambieric Acid A. J. Am. Chem. Soc. 2012, 134, 11984-11987. [CrossRef]

348. Nicolaou, K.; Aversa, R.J. Maitotoxin: An inspiration for synthesis. Isr. J. Chem. 2011, 51, 359-377. [CrossRef] 
349. Vale, C.; Antero, A.; Martín, V. Pharmacology of ciguatoxins. In Phycotoxins, Chemistry and Biochemistry; Alfonso, L.B.A.A., Ed.; Wiley Blackwell: Hoboken, NJ, USA, 2015; pp. 23-48.

350. Yin, K.; Zimmermann, K.; Vetter, I.; Lewis, R.J. Therapeutic opportunities for targeting cold pain pathways. Biochem. Pharmacol. 2015, 93, 125-140. [CrossRef] [PubMed]

351. Reyes, J.G.; Sánchez-Cárdenas, C.; Acevedo-Castillo, W.; Leyton, P.; López-González, I.; Felix, R.; Gandini, M.A.; Treviño, M.B.; Treviño, C.L. Maitotoxin: An enigmatic toxic molecule with useful applications in the biomedical sciences. In Seafood and Freshwater Toxins: Pharmacology, Physiology and Detection; Botana, L.M., Ed.; CRC Press: Boca Raton, FL, USA, 2014 ; pp. 677-694.

352. Murata, M.; Yasumoto, T. The structure elucidation and biological activities of high molecular weight algal toxins: Maitotoxin, prymnesins and zooxanthellatoxins. Nat. Prod. Rep. 2000, 17, 293-314. [CrossRef] 